\title{
Opium for the Masses? Conflict-Induced Narcotics Production in Afghanistan
}

\author{
JO THORI LIND \\ KARL OVE MOENE \\ FREDRIK WILLUMSEN
}

CESIFO WORKING PAPER NO. 2573

CAtegory 2: Public ChOICE

MARCH 2009

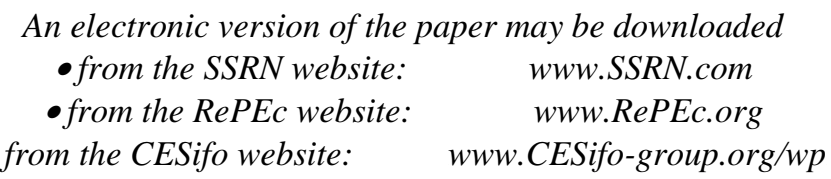




\title{
Opium for the Masses? Conflict-Induced Narcotics Production in Afghanistan
}

\begin{abstract}
We show that the recent rise in Afghan opium production is caused by violent conflicts. Violence destroys roads and irrigation, crucial to alternative crops, and weakens local incentives to rebuild infrastructure and enforce law and order. Exploiting a unique data set, we show that Western hostile casualties, our proxy for conflict, have strong impact on subsequent local opium production. This proxy is shown to be exogenous to opium. We exploit the discontinuity at the end of the planting season: Conflicts have strong effects before and no effect after planting, assuring causality. Effects are strongest where government law enforcement is weak.
\end{abstract}

JEL Code: D74, H56, K42, O1.

Keywords: conflict, narcotics production, resource curse, Afghanistan.

\author{
Jo Thori Lind \\ j.t.lind@econ.uio.no \\ Karl Ove Moene \\ k.o.moene@econ.uio.no \\ FredrikWillumsen \\ f.h.willumsen@econ.uio.no
}

\author{
Department of Economics \\ University of Oslo \\ PB 1095 Blindern \\ 0317 Oslo \\ Norway
}

February 20, 2009

This paper is part of the cooperation between ESOP, Department of Economics, University of Oslo and CSCW at the International Peace Research Institute, Oslo (PRIO).We are grateful to Astrid Sandsør for excellent research assistance, and to Jens Chr. Andvig, Erik Biørn, Joan Esteban, Raquel Fernández, Jon H. Fiva, Steinar Holden, Alfonso Irarrazabal, Rocco Macchiavello, Halvor Mehlum, Debraj Ray, Carl-Erik Schulz, Tore Schweder, Gaute Torsvik, and Bertil Tungodden for useful discussions. We have also benefited from comments from participants at the Annual Meeting of the Norwegian Economics Association, Oslo 2008, the CMI development seminar, Bergen 2008, the ESOP/CSCW Workshop on Conflicts and Economic Performance, Oslo 2008, the Nordic Conference in Development Economics, Stockholm 2008, the ESOP workshop on Development and Inequality, Oslo 2008, and the 4th Annual Conference on Economic Growth and Development, New Delhi 2008. 


\section{Introduction}

Opium production in Afghanistan has helped finance holy wars against Soviet occupation, violent power contests among warlords, the rise of Taliban and its way to power, and the present resistance against Western intervention. What is less well known is how conflicts have spurred opium production as well. This paper shows how the recent rise in poppy cultivation in Afghanistan can be understood as a direct consequence of the rising violent conflicts.

We think of this as a stark illustration of how war conditions are both destructive and creative. Military actions destroy existing lines of production, and new illegal opportunities arise as law enforcement becomes weaker. The traditional explanation for why the production of illegal substances is so high in conflict areas, however, focuses on drugs-for-arms strategies. This explanation rests on centralized power within rebel organizations or governments, where strongmen organize the growing of illegal substances to finance military campaigns.

We emphasize a reverse mechanism, what we call conflict-induced narcotics production. It rests on more fragmented power where local producers and leaders react to military activities by raising drug production; not because they want to hoard cash to buy arms, but because the production decisions reflect a new social and economic situation, and a shorter time horizon. In the case of Afghanistan, the key is the observation that opium cultivation requires a minimum of investments and provides a maximum of economic turnover. These are desirable features under the political instability generated by conflict.

Why do production decisions change? Opium is more drought resistant than wheat, the main alternative crop, and opium does not require road transportation. Military activities that destroy infrastructure such as irrigation and roads therefore make opium relatively more profitable. Hence, farmers and local warlords shift to opium because it is less affected by the fighting and can more easily be produced and sold in the new conflict environment.

Violence and political instability also make it possible to ignore the law (large production notwithstanding, opium has been illegal in Afghanistan since 1945 (UNODC, 1949)). As David Keen (2000, p. 22) stresses, conflicts should be regarded as "the emergence of an alternative system of profit, power, and even protection." The social stigma attached to illegal activities easily vanishes, expected punishment declines, and local protection is taken over by militia leaders and warlords. A fragmented state enables warlords and local leaders to earn a living by protecting poppy cultivators, opium traders, and laboratories. Faced with higher risks of violence and hostile take-overs, local militia leaders also find it less profitable to rebuild destroyed infrastructure, making conflict-induced opium production persistent.

The soaring of opium production in recent years amounts to more than a doubling from 2002 to 2007. Since the physical conditions and climate are extremely well suited for opium production in Afghanistan, ${ }^{1}$ a large change in opium production can come about by a small alteration in incentives caused by conflicts. The physical and social conditions for poppy cultivation and heroin production constitute the opium curse of Afghanistan, we argue, where illegal displaces legal production. ${ }^{2}$

To empirically test the main mechanism of how violent conflicts induce subsequent opium

\footnotetext{
${ }^{1}$ Average yield in Afghanistan is about $40 \mathrm{~kg} / \mathrm{ha}$ compared to for instance only about $10 \mathrm{~kg} / \mathrm{ha}$ in Burma, the former major global producer of illicit opium (UNODC, 2008). In Indian test stations, which generally have much higher yields than an average farmer, yields of a maximum of $60 \mathrm{~kg} /$ ha have been obtained (Kapoor, 1995, p. 66).

${ }^{2}$ This is a variant of the "resource curse" (see e.g. Sachs and Warner, 1995, 1997, 2001). In general, the resource curse can be a misnomer. In most cases it is the combination of bad institutions and "lootable" resource rents that leads to these kinds of development failures (Mehlum et al., 2006). The problem in Afghanistan is not the resources or high productivity of opium per se, but rather the circumstances for resource rent extraction. In fact, the whole Afghan opium trade becomes so valuable just because the country has such bad institutions. Institutions that obeyed international conventions would restrict opium production to legal medical use.
} 
production, we have gathered a unique data set with information from the 329 Afghan districts from 2001 to 2007 on areas under opium cultivation and the localization of conflict. To measure violent conflicts, we use information on the occurrence of Western hostile casualties. Typically, hostile casualties occur when soldiers are killed in operations that destroy infrastructure in contested areas. The well-known Operation Medusa in 2006 is a clear example: 20 NATO soldiers died as they were throwing grenades into wells and through doors in a Taliban stronghold where NATO forces controls $2 / 3$ of the area (the incident is further discussed in Section 4). Clearly, hostile casualties are associated with material destruction, political risk, declining law enforcement and, as we demonstrate, rising opium production. But how do we know which way causality runs - and thus that a substantial part of the rise in opium production is conflictinduced?

Before 2001 there are no consistent conflict data, but we provide a brief historical account of how the outbreak of non-opium conflicts spurred opium cultivation. From 2001 onward we have information on casualties in NATO's ISAF forces and US forces in Operation Enduring Freedom. To minimize the endogeneity problem, we do not attempt to use information on Afghan casualties as these may stem from conflicts over control of opium fields. We document below that the Western forces are not involved in poppy eradication or other actions against narcotics production, both from the forces' mandates and by documenting a lack of correlation between Western casualties and opium eradication. Both clearly indicate that our measure of conflict is exogeneous to opium production.

Our regressions show that there is a strong positive relationship between Western casualties and subsequent opium production. We also undertake a number of tests to verify that the line of causality indeed goes from conflict to opium production. First, we compare the impacts of fighting on opium production just before and just after the planting season. There is a clear discontinuity: only conflict before the planting season has an impact on production. The direction of causality is also confirmed by a Granger causality test - conflict in one year induces opium production in the next, whereas opium production in one year does not induce fighting the year after.

To further check for simultaneity biases we instrument opium production by deviations from normal rainfall. This exercise indicates that there is no causal link from opium production to conflict, and hence that the correlation must be driven by conflict leading to opium production. To test for whether opium production could be caused by the mere presence of Western soldiers, and not by fighting in itself, we compare the effect of hostile and non-hostile casualties on poppy cultivation. Hostile casualties have a strong effect whereas non-hostile casualties have no effect. Finally, we show that the effect of conflict on opium production is much lower when law enforcement is good, supporting our assertion that conflict-induced narcotics production relies on institutional failure.

In a number of countries there is correlation between violent conflict and drugs production. The small literature that explores the links between conflict and drugs emphasizes the role of civil war and how drugs production help finance rebellion activity - what we denote drugs-for-arms strategies. The identification of a positive effect of coca production on conflicts in Colombia is derived convincingly by Angrist and Kugler (2008). They explore variations across regions of how an exogenous increase in coca prices affects rebellion activities. Cornell (2005) provides a further survey of some other case studies.

The link between conflict and local economic activities is also the topic of two recent papers by Dube and Vargas (2008) and Hidalgo et al. (forth.). Dube and Vargas (2008) investigates how different types of price shocks give rise to subsequent violent conflicts in Colombia: A price drop in a labor-intensive activity works through the local labor market by lowering the opportunity cost of joining the militia; a price increase of capital-intensive goods works through the gains from rent appropriation. Similarly, Hidalgo et al. (forth.) shows that adverse economic 
shocks cause the rural poor to invade large land holdings in Brazil, and that this effect is more pronounced in areas where the inequality in land holdings is high.

All these contributions consider the effects of economic shocks on subsequent conflict. Our mechanism, however, highlights the effects of conflict shocks on subsequent economic activity. Guidolin and La Ferrara (2007) take a similar point of view in their exploration of how violence affect the value of firms extracting "conflict diamonds" in Angola. Although the literature cited above demonstrates that we cannot rule out the link from economic shocks to conflicts, the novelty of our paper is the reverse effect - what we denote conflict-induced narcotics production. This effect is hardly discussed in the literature. ${ }^{3}$ Our efforts are thus particularly oriented toward demonstrating empirically the effect of conflict shocks on economic activity, for the case of Afghanistan.

In Section 2 we provide a brief overview of the background of opium in Afghanistan emphasizing how large increases follow the outbreak of serious conflicts. Section 3 provides a simple model that highlights the main mechanisms behind the association between conflicts and opium cultivation. Section 4 contains our empirical findings and a number of tests for causality and robustness. Section 5 concludes.

\section{Background}

Afghanistan's dominant role in the world opium production does not go back more than three decades, as can be seen from Table 1. ${ }^{4}$ The low initial production may seem puzzling as the favorable physical circumstances for growing and processing opium seem to have been almost the same for decades. The soil and climate conditions fit well with opium production. Opium poppies can grow almost everywhere in Afghanistan. The cultivation requires a factor endowment of much labor ${ }^{5}$ and little land, which fits the Afghan situation. In addition, dried raw opium takes up little space relative to its value. It can easily be stored and kept as savings, and can readily be exchanged even in times of serious conflicts. The processing and transport facilities seem to be largely unaffected by war conditions. The process of transforming raw opium to heroin is also fairly simple requiring only commonly available chemicals and a rudimentary laboratory. ${ }^{6}$ These laboratories can easily be established and operated. Today Afghanistan has a large number of them. Most of the laboratories are small and family run, producing about $10 \mathrm{~kg}$ per day (UNODC, 2003, p. 139f). Some are even mobile, which is particularly important in areas with violent conflicts and contested power.

Since these physical circumstances have been the same for decades, an explanation for the shift in opium production must be sought in the social and economic conditions. We assert that it is the emergence of an alternative system of profit, power and protection, associated with increasing conflicts, that explains the rise in opium production. Looking back over the recent three decades, significant increases in opium production follow outbreaks of serious conflicts.

The first significant shift in poppy cultivation came after the Soviet occupation in 1979 (UNODC, 2003, p. 89). The uprising against the Soviets was not a reaction by the state elite

\footnotetext{
${ }^{3}$ The only paper we are aware of is the study of coca production in Colombia by Díaz and Sánches (2004). Their mechanism is that an increase in the power and territorial control of the rebel groups lead to a rise in coca production, since only rebel groups produce coca. Economic agendas in civil wars are also discussed in an edited volume by Mats Berdal and David Malone (2000)

${ }^{4}$ The table is compiled from different sources and hence the figures are not necessarily directly comparable. The upward trend, however, is very clear.

${ }^{5}$ To collect the opium from the poppy, the pod of the plant has to be cut, a procedure known as lancing. As all the poppies do not mature at the same time, the farmer has to go over the same area several times lancing the mature pods. Once a pod has been cut open, the opium oozes out and is collected. This process is repeated until the plant stops yielding.

${ }^{6}$ See e.g. Booth $(1996,77 f)$ for details of the process.
} 
Table 1: Opium production in Afghanistan in a historical perspective

\begin{tabular}{cc}
\hline Year & Production \\
\hline 1932 & 75 \\
1956 & 12 \\
1972 & 100 \\
1980 & 200 \\
1990 & 1570 \\
2000 & 3276 \\
2007 & 8200 \\
\hline
\end{tabular}

Notes: Production in metric tonnes.

Source: CCINC (1972); UNODC (2003, 2007)

in Kabul. The old regime lacked the organizational base to lead any popular movement. It favored small local power holders, mainly landlords and khans, and the uprising against the Soviets "started as a mass-based movement [...] without any unified national leadership" (Rubin, 2002, pp. 184-5). Opium profits played an essential role in the uprising. As one observer remarks, "Soviet invasion of the country threw the society into chaos, and gave rise to ineffectual governments lacking control over the whole territory. This prompted unscrupulous warlords to take advantage of the situation by encouraging farmers to shift to poppy cultivation" (Misra, 2004, p. 127). Similarly, Rashid (2000, p. 119) concludes that "[e]ver since 1980, all the Mujaheddin warlords had used drugs money to help fund their military campaigns and line their own pockets". There are indications that covert US operations helped boost both the production of opium and smuggling of heroin through Pakistan (McCoy, 1991; Haq, 1996), and the occupation also brought Russian criminals into the drug networks in Afghanistan and Pakistan. This facilitated exports of opium to far off countries, and Afghan heroin was now smuggled through Central Asia, Russia, the Baltic countries and finally into Europe (Rashid, 2000, p. 120).

After the Soviet withdrawal in 1989, and in particular after the fall of Najibullah's regime in 1992, warlords who earlier were unified against the Russians started to fight each other. It was a violent power struggle with shifting alliances between ethnic groups and between local commanders. Amalendu Misra (2004, p. 52) claims that between 1992 and 1996 "every major group had both allied with and fought against every other major group at one time or another" (see also Giustozzi, 2000; Kaplan, 2001). At the same time agriculture and trade revived. But "[m]uch of this renewed production took the form of opium growing, heroin refining, and smuggling; these enterprises were organized by combines of mujahidin parties, Pakistani military officers, and Pakistani drug syndicates." (Rubin, 2002, p. 183). The acceleration of opium production around 1989 is also noted by UNODC (2003, p. 90). Poppy cultivation in Pakistan was dramatically reduced as the government started to fight the narcotics Mafia that had developed in the Pakistani armed forces. Warlords in Afghanistan took over the production.

When Taliban entered the scene in 1994, it acted as other warlords when it came to opium production. According to Rashid (2000), the area for poppy cultivation was expanded and new trade and transport routes were established as Taliban fought its way to power. Taliban also extracted parts of the opium profits through levying the traditional ushr and zakat taxes on the opium traders (UNODC, 2003, p. 92). The taxes on opium production were interpreted as a sign of its religious and political acceptance.

After the US intervention in 2001 joined by NATO forces, opium production has been on a dramatic rise. Since 2002 until today it has more than doubled, see Figures 1 and $2 .{ }^{7}$ In

\footnotetext{
${ }^{7}$ The extremely low level of opium production in 2001 is due to the Taliban's enforced ban on poppy cultivation
} 
Figure 1: World production of opium and world market opium prices.

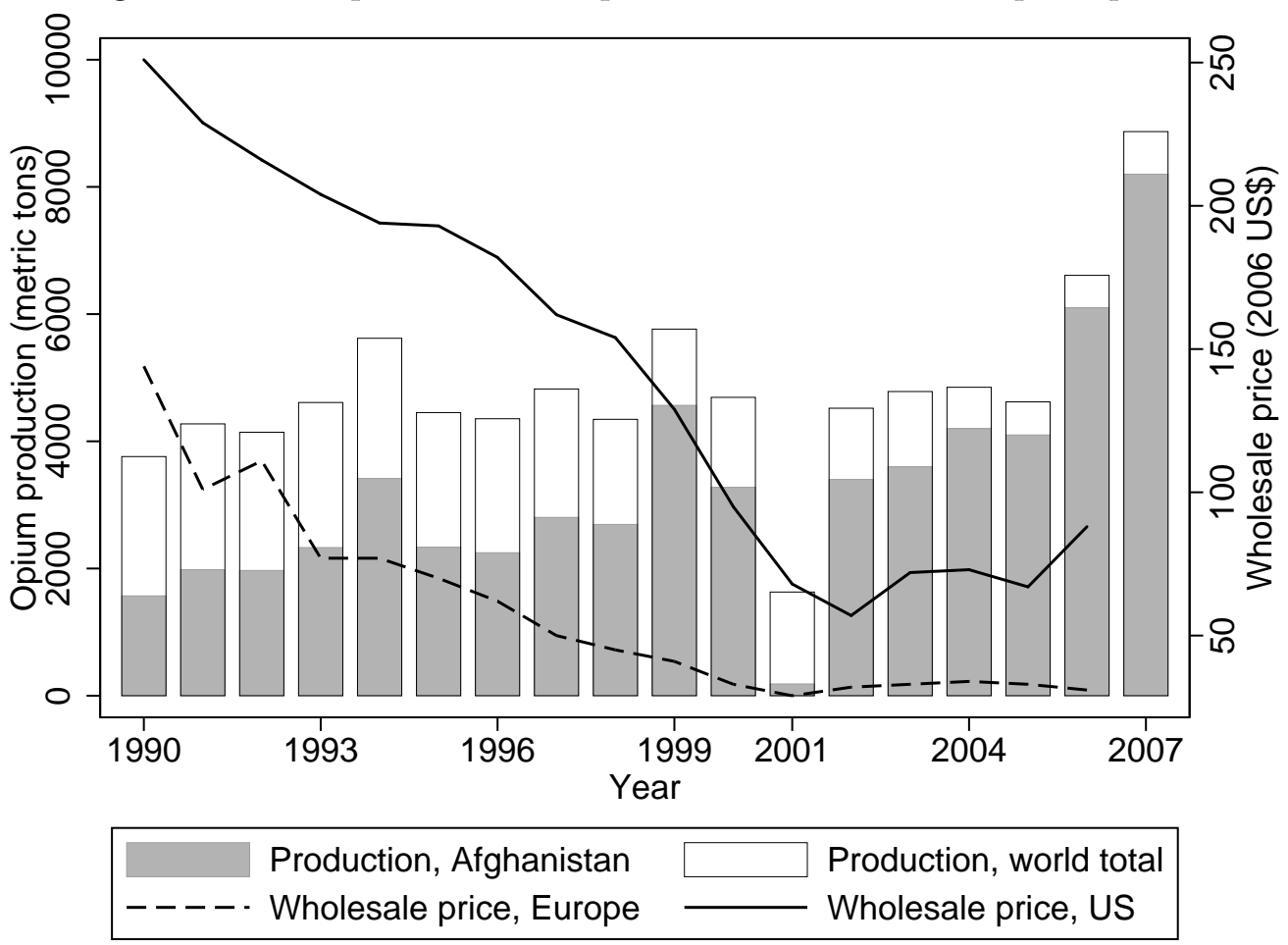

Notes: Wholesale price is in 2006 US \$ / gram. Opium production is "Potential opium production" in metric tons, as measured by UNODC (2008). Since 2000, the only competitor to Afghan opium is opium from Myanmar. During the 90's, also Lao PDR, Pakistan, Vietnam, Mexico, and Colombia produced noticeable amounts of opium. Source: UNODC (2008).

the Figures, we see that Afghanistan currently produces more than 90 per cent of the world's illicit production of opium. Alongside the expansion of Afghani opium production over the last 15 years, wholesale prices have plummeted both in Europe and the US. Figure 2 also plots the number of Western casualties who died in hostile encounters in the period 2001 to 2007. Already here we see that there is a strong correlation between the two time-series. At this level, however, it is not possible to say anything about causation. In the empirical part of this paper, we will use disaggregated data on Western casualties and opium production figures from UNODC to investigate the relationship between conflict and opium production more thoroughly.

\section{Conflict-induced opium: the mechanisms}

Opium and wheat are the main alternative crops for farmers in Afghanistan. The cultivation of the two crops differ systematically, in that wheat production in Afghanistan is much more dependent on proper infrastructure than opium. In a joint study by the World Bank and UNODC, Martin and Symansky (2006, p. 26) conclude that

"Opium is relatively drought-resistant, making its cultivation easier than wheat in areas where irrigation is limited. Moreover, dry opium is easy to store and transport,

this year. The ban is thoroughly discussed in Farrell and Thorne (2005) and the rest of the articles in the Special Focus issue on Taliban and Opium in the International Journal of Drug Policy (Volume 16, issue 2, 2005). 


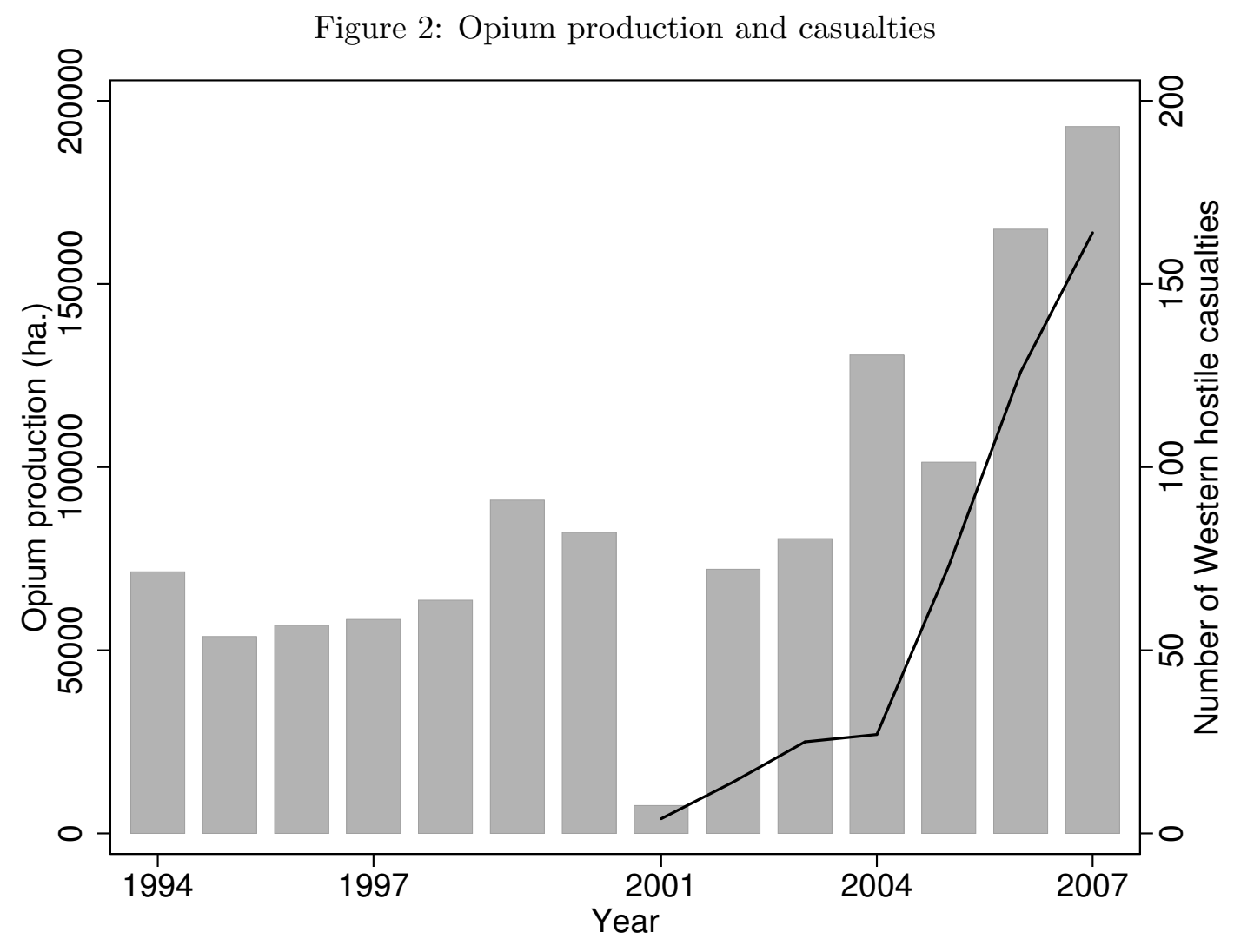

Notes: Bars depict hectares of land devoted to opium production and the line depicts hostile casualties. The extremely low level of opium production in 2001 is due to the Taliban's ban on poppy cultivation in this year (see discussion and references in footnote 7).

Source: UNODC (2007) and iCasualties.org.

which, given the poor state of roads and stocking facilities in Afghanistan, gives it an advantage over other crops." 8

We incorporate these differences in a highly stylized model that focuses on the relationship between a local leader, called the warlord, ${ }^{9}$ and local farmers (sharecroppers or smallholders). In the model three interrelated decisions are highlighted. First, the warlord decides on investments in infrastructure, such as irrigation, local roads, and storing facilities for agricultural products. Second, the warlord or his associates offer a price per $\mathrm{kg}$ raw opium to farmers. Third, each plot of land is divided between wheat and opium cultivation either by the farmer or the warlord, depending on the strength of warlord control in the area.

Both land ownership and warlord dominance vary across farms and districts. As Mansfield (2001, 2004, 2005) has convincingly emphasized, the group of poppy cultivators in Afghanistan is rather heterogeneous as it differs in holdings of assets and in dependence on land owners and warlords. The concept of an idealized representative farmer is therefore misleading; We aim at

\footnotetext{
${ }^{8}$ Similar points have been made by Barth (2008, pp. 44-45) and UNODC (2003, p. 89 and p. 99).

${ }^{9}$ Many Taliban leaders should be considered regular warlords. Several Taliban leaders in fact have a background as warlords. The legendary warlord Jalaluddin Haqqani, for instance, "a hero to the CIA and wealthy Arab backers during the fight against the Soviet invaders", and by many considered to be un-Islamic, is currently the principal military commander of the Taliban (quote from Independent, 2008). For more on the neo-Taliban insurgency, see Giustozzi (2007).
} 
a set up that in a simple way delievers results that are robust to variations in local power and land ownership. ${ }^{10}$

\subsection{Basic model of production}

In all cases we consider, the farmer has access to a plot of land suitable for growing both wheat and opium as cash crops.

\section{Wheat}

Let $F_{t}$ indicate marketable wheat production in period $t,{ }^{11}$ and let $k_{t}$ indicate the level of infrastructure such as irrigation, roads, and storage facilities in the local community. The farmer is assumed to have enough household labor to cultivate wheat efficiently on the entire plot. The productivity per hectare is $f\left(k_{t}\right)$, where $f$ is increasing and concave. Total production of wheat on the plot is thus

$$
F_{t}=f\left(k_{t}\right)\left(1-n_{t}\right)
$$

The income from wheat production depends on land ownership and control. If the warlord owns the land, he obtains his share $\alpha_{L}$ of the wheat production, and the farmer obtains his share $\alpha_{F}=1-\alpha_{L}$. If the farmer owns the land, his share is $\alpha_{F}=1$ and the warlord obtains no rents from wheat production. If neither the warlord nor the farmer owns the land, $\alpha_{F}+\alpha_{L}<1$. Any use of hired labor is covered by $\alpha_{F}$ of the production value.

\section{Opium}

Let $G_{t}$ indicate opium production in period $t$. Opium's robustness against drought, irregular irrigation, and lack of transport and storing facilities means that opium production is less dependent on the quality of the infrastructure $k_{t}$ than wheat. We capture this by simply assuming that the production of opium is independent of infrastructure. ${ }^{12}$ It is, however, much more labor intensive to cultivate opium than wheat, see e.g. footnote 5 above. With a given household labor, the farmer therefore has decreasing returns in opium production since the opium production per hectare land declines as his poppy field expands. To capture the decreasing returns to scale, combined with the sensible conditions that the marginal productivity of the first parcel of land is positive but finite, and that with no land devoted to opium there is no yield, we postulate the following production function

$$
G_{t}=\left(n_{t}+\bar{n}\right)^{\mu}-\bar{n}^{\mu} \quad \text { with } \quad \mu<1, \quad \bar{n} \geq 0,
$$

where $\bar{n}$ determines the initial marginal productivity, since the marginal productivity of the first parcel is $\mu(\bar{n})^{\mu-1}$. With $\bar{n}=0$, the function collapses to a standard Cobb-Douglas production function.

\footnotetext{
${ }^{10}$ UNODC (2004) report that in the 2003-2004 season, $87 \%$ of poppy growers and $81 \%$ of non-poppy growers decided what to plant on their own. There is some geographical variation, however, a larger proportion of farmers do not decide what to plant on their own in the south than in the rest of the country. Land ownership also varies across the country, although the vast majority of farmers own the land they farm. Sharecropping is more common in the North Eastern and Eastern regions (UNODC, 2004, Table 23). In some parts of the literature the role of the traditional credit system, salaam, is also emphasized as a stimulant to opium production. This is further discussed in Willumsen (2006), who finds that the empirical support for this is limited to a small group of farmers who devote all their land to poppy cultivation.

${ }^{11}$ Clearly, most Afghani farmers also produce wheat for own subsistence consumption which is neither dependent on roads nor on storing facilities. Therefore we should think of $F_{t}$ as cash crops cultivated beyond subsistence levels.

${ }^{12}$ The conclusions we draw are only dependent on an assumption that the elasticity of opium production with respect to infrastructure $k_{t}$ is sufficiently low relative to that of wheat production.
} 
The income from opium cultivation is divided between the farmer, the traders, and the warlord. The traders work under warlord protection, and we treat them as his close associates without a separate role in the model. The income of the warlord is thus the difference between the selling price of opium $P_{t}$ at the border and the price $p_{t}$ of buying opium at the farm gate. The farmer obtains the farm gate price $p_{t}$ per $\mathrm{kg}$ raw opium that he produces.

While the share that the warlord may obtain from wheat production is given by old customs and conventions, the warlord and his associates simply set the farm gate price $p_{t}$. Thus the warlord has more power over the opium trade than over the wheat trade. His power, however, may be constrained by governmental law enforcement (or the quality of institutions), modeled by the parameter $\theta_{t} \leq 1$, where $1-\theta_{t}$ can be thought of as the probability of confiscation or eradication of the opium production. More generally, a higher level of $\theta_{t}$ captures a situation where local leaders and farmers more safely can ignore the law. Thus, a high $\theta_{t}$ captures confidence in a local system of power and protection.

To sum up, with a wheat price normalized to 1, the expected profits accruing to the warlord $\pi_{L}$ and the farmer $\pi_{F}$ in period $t$ can be expressed as follows

$$
\begin{aligned}
& \pi_{L}=\theta_{t}\left(P_{t}-p_{t}\right) G_{t}+\alpha_{L} F_{t} \\
& \pi_{F}=\theta_{t} p_{t} G_{t}+\alpha_{F} F_{t}
\end{aligned}
$$

To capture the heterogeneity in power structures across Afghanistan, we consider two ways of determining $n_{t}$ and $p_{t}$, imperfect and complete warlord control, both for a given level of $k_{t}$.

\subsection{Imperfect versus complete warlord control}

\section{Imperfect warlord control}

The most common case is when the farmer decides the allocation of land between opium $n_{t}$ and wheat $\left(1-n_{t}\right)$. As stated in footnote 10, almost 90 per cent of Afghan farmers claim that they have this independence. Yet, the warlord treats his poppy cultivators as his hirelings. The warlord sets an effort-inducing price $p_{t}$ and let the farmer decide how much to produce. In this sense the warlord resembles the putter-out merchant of the early textile industry in England. David Landes (1969) describes how "the artisan found himself bound to the merchant who supplied his raw materials and sold his finished work" (p. 43). ${ }^{13}$ Hence, we have

$$
\begin{aligned}
\pi_{L}\left(k_{t}\right) & =\max _{p_{t}}\left\{\theta_{t}\left(P_{t}-p_{t}\right)\left[\left(n_{t}+\bar{n}\right)^{\mu}-\bar{n}^{\mu}\right]+\alpha_{L} f\left(k_{t}\right)\left(1-n_{t}\right)\right\} \\
\text { s.t. } n_{t} & =n\left(p_{t}, k_{t}, \theta_{t}\right) \equiv \arg \max _{n_{t}} \pi_{F} \\
\text { where } \pi_{F} & =\theta_{t} p_{t}\left[\left(n_{t}+\bar{n}\right)^{\mu}-\bar{n}^{\mu}\right]+\alpha_{F} f\left(k_{t}\right)\left(1-n_{t}\right)
\end{aligned}
$$

We first determine the allocation of land for a given farm gate price $p_{t}$. Solving the farmer's optimization problem, we find

$$
n\left(p_{t}, k_{t}, \theta_{t}\right)= \begin{cases}0 & \text { if } p_{t} \leq \frac{\alpha_{F} f\left(k_{t}\right)}{\mu \theta_{t}} \bar{n}^{1-\mu} \\ \left(\frac{\mu \theta_{t} p_{t}}{\alpha_{F} f\left(k_{t}\right)}\right)^{\frac{1}{1-\mu}}-\bar{n} & \text { if } p_{t}>\frac{\alpha_{F} f\left(k_{t}\right)}{\mu \theta_{t}} \bar{n}^{1-\mu}\end{cases}
$$

The fraction of land $n_{t}$ used for opium cultivation is increasing in the price $p_{t}$ that the landlord offers and in the confidence in local protection $\theta$. Also, if $\bar{n}$ is sufficiently large relative to the farm-gate price $p_{t}$ and the profitability of wheat $\alpha_{L} f\left(k_{t}\right)$, the farmer prefers to produce no

\footnotetext{
${ }^{13}$ Landes also observed how the artisans were "caught on a treadmill of debt-his finished work mortgaged in advance to his creditor" (p. 43). Similarly Mansfield (2001) emphasizes the role of the credit system salaam in his description of poppy cultivation in Afghanistan.
} 
opium. If we allowed $\bar{n}$ and $\theta$ to vary between farmers and districts, capturing the heterogeneity in circumstances among farmers emphasized by e.g. Mansfield (2001, 2004, 2005), the model can account for the fact that only a fraction of farmers produce opium. If law enforcement is strong (low $\theta$ ), the farm gate price of opium that the warlord must pay in order to induce poppy cultivation can be prohibitively high.

For simplicity, we from now on focus on the case where $n\left(p_{t}, k_{t}, \theta_{t}\right)>0$. The fraction of land dedicated to opium production $n_{t}$ is declining in the opportunity costs of opium production - the farmers' share of the wheat productivity $\alpha_{F} f\left(k_{t}\right)$ relative to the land productivity of opium $\mu$. Next, we find the profit maximizing price $p_{t}$ that the warlord offers:

$$
p_{t}=\frac{P_{t}}{\alpha_{L} / \alpha_{F}+1 / \mu-[(1-\mu) / \mu]\left[\bar{n} /\left(n_{t}+\bar{n}\right)\right]^{\mu}}
$$

When $\bar{n}=0$, the Cobb-Douglas case, the optimal farm gate price $p_{t}$ is a mark-down of the selling price $P_{t}$, where the mark-down is a constant $1 /\left(1 / \mu+\alpha_{L} / \alpha_{F}\right)<1$. It is a constant because the supply of land for opium has constant elasticity. Thus, in this case the price $p_{t}$ is independent of conflict-related destruction of infrastructure $k_{t}$ and confidence in local protection $\theta_{t}$; such changes show up solely as quantity effects: Opium production goes up and wheat production declines. When $\bar{n}>0$, the price also depend positively on infrastructure $k_{t}$ and negatively on the confidence in illegality $\theta_{t}$ via $n_{t}$. We then easily see that $n_{t}$, the amount of land dedicated to opium production, is decreasing in infrastructure $k_{t}$ and increasing in the confidence in illegality $\theta_{t}{ }^{14}$

\section{Complete warlord control}

The second case is when the warlord has complete control over both the allocation of labor $n_{t}$ and the opium price to the farmer $p_{t}$, but he faces the participation constraint of giving the farmer at least $c$. The warlord's problem becomes

$$
\pi_{L}\left(k_{t}\right)=\max _{p_{t}, n_{t}}\left[\theta_{t}\left(P_{t}-p_{t}\right)\left[\left(n_{t}+\bar{n}\right)^{\mu}-\bar{n}^{\mu}\right]+\alpha_{L} f\left(k_{t}\right)\left(1-n_{t}\right)\right] \text { s.t. } \pi_{F} \geq c
$$

The warlord chooses $n_{t}$ to maximize production, and then $p_{t}$ to satisfy the participation constraint with equality. Hence

$$
\begin{aligned}
n_{t} & =\left[\frac{\mu \theta_{t}}{\left(\alpha_{L}+\alpha_{F}\right) f\left(k_{t}\right)} P_{t}\right]^{\frac{1}{1-\mu}}-\bar{n} \\
p_{t} & =\frac{c-\alpha_{F} f\left(k_{t}\right)\left(1-n_{t}\right)}{\theta_{t}\left[\left(n_{t}+\bar{n}\right)^{\mu}-\bar{n}^{\mu}\right]}
\end{aligned}
$$

Again, conflict-related destruction of infrastructure $k_{t}$ and the corresponding rise of confidence in illegality $\theta_{t}$ have direct quantity effects: Opium production goes up and wheat production goes down. The farm-gate opium price also varies with $k_{t}$ and $\theta_{t}$, as the price is set at the lowest level that satisfies the participation constraint.

\footnotetext{
${ }^{14}$ We have two equations, (1) and (2), that determine $p_{t}$ and $n_{t}$ for every level of $k_{t}$. Inserting $n_{t}$ in $(2)$ and differentiating, we obtain $d p_{t} / d n_{t}<0$. Then, from (1) we find

$$
\frac{d n_{t}}{d k_{t}}=\frac{-p_{t} A f^{\prime}\left(k_{t}\right) / f\left(k_{t}\right)}{1-\left(d p_{t} / d n_{t}\right) A}<0 \quad \text { where } \quad A=\frac{1}{1-\mu}\left[\frac{\mu \theta p_{t}}{\alpha_{F} f\left(k_{t}\right)}\right]^{\frac{\mu}{1-\mu}}\left[\frac{\mu \theta}{\alpha_{F} f\left(k_{t}\right)}\right]>0
$$
}




\subsection{Investments in infrastructure}

The determination of $k_{t}$ is analogue in both cases considered above. Recall that constructing and maintaining irrigation and other important infrastructures is normally controlled by the warlord, and that the warlord's incentives depend on the degree to which his power is contested. The warlord decides on $k_{t}$ taking into account the profits he receives from the agricultural production (both wheat and opium) and the risk he faces of being overthrown - either by competing warlords, by the Kabul government, or by Western forces. Overthrown, the warlord would not be able to keep any locally invested assets. One reason could be that the new power holder considers the warlord's property illegitimate.

The value of the power position of a warlord with a level of infrastructure $k_{t}$, is denoted by $V\left(k_{t}\right)$. This value can be expressed as

$$
V\left(k_{t}\right)=\max _{k_{t+1}}\left\{\pi_{L}\left(k_{t}\right)+k_{t}(1-\delta)-k_{t+1}+\beta(1-\gamma) V\left(k_{t+1}\right)\right\}
$$

where $\beta$ is the discount factor of the warlord, $\delta$ is the depreciation rate of infrastructure (or, if one like, the rate of expected destruction in low level conflicts), and $\gamma$ denotes the probability that the warlord is overthrown in the next period. Note that we have normalized the continuation value of the state in which the warlord has been overthrown to 0 , and that we assume this to be an absorbing state.

To find the effects of conflict on the long term development of infrastructure, we solve (3) with the relevant expression of $\pi_{L}\left(k_{t}\right)$, which again depends on the warlord's power over the allocation of land dedicated to opium production $n_{t}$. The first order condition for the maximization problem can be written $\beta(1-\gamma) V^{\prime}\left(k_{t+1}\right)=1$, while the envelope condition states $V^{\prime}\left(k_{t}\right)=d \pi_{L} / d k_{t}+1-\delta$. Combining the two gives

$$
\frac{d \pi_{L}}{d k_{t}}=\frac{1}{\beta(1-\gamma)}-(1-\delta)
$$

With a per period risk of being overthrown equal to $\gamma$, the warlord's expected length in power is equal to $1 / \gamma$. Thus, when conflicts become more likely, the expected horizon becomes shorter, and the warlord invest less in infrastructure (as he would in any other local asset where his property right depends on his incumbency). A higher conflict risk $\gamma$ therefore leads to a lower level of infrastructure $k_{t}$, which again leads to higher opium production. Similarly, when conflicts are expected to destroy future infrastructure (i.e. $\delta$ is high), we see from (4) that the warlord initiates less rebuilding of infrastructure today.

\subsection{Opium and conflict}

In sum, our model shows:

Proposition 1. The factors (a) destruction of infrastructure (lower $k_{t}$ ), (b) confidence in local protection and low fear of external law enforcement (higher $\theta_{t}$ ), and (c) political instability (higher $\gamma$ ) all lead to a rise in opium production, irrespective of land ownership and of who decides what crop to cultivate.

Intuitively, the destruction of infrastructure erodes the profitability of wheat as a cash crop, and thus lowers the opportunity costs of opium production. Lower opportunity costs mean higher opium production. The rise in illegal opportunities caused by weaker law enforcement $\theta_{t}$ also stimulates opium production directly for every level of infrastructure $k_{t}$. Those who are involved in the trade expect to obtain more of the opium profits, as they feel more confident that they are protected against eradication and confiscation of profits. Hence, there is a complementarity between creation and destruction: When law enforcement declines at the same time as infrastructure is destroyed, the rise in opium production becomes particularly high. 
The parameters $\theta$ and $\gamma$ capture related aspects of secure power and property rights. $\theta$ is included to capture the impact of variations in law enforcement for a given level of $k$, while $\gamma$ is included to capture more long run perspectives, i.e. the warlord's political risk of being overthrown. An increase in political risk $\gamma$ leads the warlord to invest less in infrastructure, as his expected capital loss goes up with higher risk of conflict. Through the channels discussed in Proposition 1, this induces more opium cultivation by the farmers. The higher level of opium production means that the opportunity costs of investing in infrastructure rises even further.

It should also be noticed that a politically strong warlord who has incomplete control over farmers and who obtains a low share of legal agricultural rents, can be particularly bad for economic development. When the farmer has power to decide what to grow, the warlord must create bad opportunities for wheat production in order to induce the farmer to choose opium, from which the warlord benefits the most. Hence, higher political instability (higher $\gamma$ caused by increasing conflicts), strong underdevelopment, and high opium production go together as the warlord would like to allocate more labor to opium production than the farmers would choose themselves.

\section{Conflict-induced opium: The magnitudes}

In our model, conflict has three important properties that link it to subsequent opium production: Destruction of infrastructures $k_{t}$, increased confidence in illegality $\theta_{t}$, and higher political risk $\gamma$. We do not attempt to estimate separate effects of the three. Instead, we proxy for a combination of these by Western soldiers observed dying in hostile combats. The three characteristics are jointly observed in most battles: Soldiers are killed, the operations destroy infrastructure, and it takes place in contested areas. For instance, on the 12th day of Operation Medusa, NATO's largest offensive in Afghanistan, The Times reports that

"Heavy gates to walled compounds were blown open, a warren of Taleban tunnels and bunkers were destroyed by explosives and grenades were thrown into wells and fired through doors [...] But it is gruelling, dangerous work. At least 20 Nato troops have been killed in the battle, and [...] Nato claimed to be in control of only 65 per cent of the Panjawyi area". (The Times, 2006)

We focus on the link from conflict to opium production. As indicated above, however, we have no reason to rule out a link from opium to conflicts. Yet, the novelty of our paper is conflictinduced opium production, and our efforts are particularly oriented toward demonstrating this empirically. Clearly, this also indicates that we have to confront some endogeneity problems.

\subsection{Data and empirical strategy}

Obviously, to test the mechanism we need exogenous variation in conflict. There is no data on the direct amount of fighting available. One approach could be to use the number of combat activities by year, but data on such events are scarce and mostly based on media coverage. Also, these data have not been coded so far. More importantly, basing our empirical inference on data like these would lead us into severe endogeneity issues, as all internal power struggles between different warlords and traders over future opium production would lead us to conclude that fighting causes opium production, although in this case the causality would go the other way around. Instead, we base our measure of conflict on casualties from hostile encounters involving Western ISAF forces or US forces in the Operation Enduring Freedom (OEF). Afghani casualties are not available, but Western casualties are. The placement of Western forces is arguably more exogenous relative to opium production than more general data on where fighting occurs. 
As claimed above, Western ISAF forces do not involve themselves in fighting related to opium production. This is made clear on their web site:

"While supporting the Afghan government counter-narcotics programmes is an ISAF key supporting task, ISAF is not directly involved in poppy eradication, nor does it participate in the destruction of processing facilities, or in any military action against narcotic producers", ${ }^{15}$

and in the description of their mandate:

"ISAF aims at: [...] provide support to the Afghan government and internationallysanctioned counter-narcotics efforts through intelligence-sharing and the conduct of an efficient public information campaign, as well as support to the Afghan National Army Forces conducting counter-narcotics operations. ISAF, however, is not directly involved in the poppy eradication or destruction of processing facilities, or in taking military action against narcotic producers". ${ }^{16}$

Neither have US soldiers focused on fighting drugs: "until recently, American officials acknowledge, fighting drugs was considered a distraction from fighting terrorists." (New York Times, 2007). According to the same article, the Taliban offensive in the spring of 2006 and especially the resignation of Secretary of Defense Donald Rumsfeld in December 2006, led to a change in attitude among defense officials on the role of opium in funding the insurgency. Since the change of strategy was around the turn of the year 2006-7, we avoid using data on casualties for 2007 to predict opium production in 2008.

To verify that Western soldiers are really not involved in opium eradication, we use data on the area of opium eradicated for 2006 and 2007 from UNODC $(2006,2007)$. If we are not able to reject the null hypothesis of zero correlation between eradication and Western casualties (the data on conflict are presented below), this is a strong indication that the conflict variable we use is exogenous to opium production. The eradication is led by the Afghan government, and the figures on the size of the eradicated areas are verified by the UNODC. Unfortunately we have not been able to find verified figures on eradication from before 2006 .

The contemporaneous correlation between casualties and area eradicated in 2006 and 2007 can be found in Table 2. As seen from columns (1) and (2), there is no correlation between eradication and casualties in 2006. In 2007, the correlation is stronger but still not statistically significant, see columns (3) and (4). The reason for showing the regressions by year, and not pooling the observations across the two years, ${ }^{17}$ is that, according to the New York Times (2007) quote cited above, the American soldiers changed their strategy from 2006 to 2007. Clearly, the findings in Table 2 are very much in line with the quotes from the New York Times (2007): also in the data there seems to be evidence of a change in the US strategy from 2006 to 2007. Again, due to this change of strategy we avoid using data on casualties for 2007 to predict opium production in 2008.

The data on conflict are drawn from iCasualties.org, which base their data mostly on press releases from the US Department of Defense and CENTCOM. ${ }^{18}$ This database lists every casualty by name, cause of death, and location. We separate between hostile and non-hostile casualties, and use the reported location to measure casualties by district. Some casualties are

\footnotetext{
${ }^{15}$ http://www.nato.int/isaf/topics/recon_dev/cn.html, accessed on Aug. 28, 2008.

${ }^{16}$ http://www.nato.int/isaf/topics/mandate/index.html, accessed on Aug. 28, 2008.

${ }^{17}$ The results from pooling the data across the two years are qualitatively the same as the ones given in Table 2: We cannot reject the hypothesis that there is no correlation between conflict and eradication ( $\mathrm{p}$-value of 0.232 and 0.169 for resp. with and without control for lagged opium production).

${ }^{18}$ This is the same source used by Greenstone (2007) and Iyengar and Monten (2008) to measure casualties in Iraq.
} 
Table 2: Correlation between eradication of opium and Western hostile casualties in 2006 and 2007

\begin{tabular}{lrrrr}
\hline & \multicolumn{1}{c}{$(1)$} & \multicolumn{1}{c}{$(2)$} & \multicolumn{1}{c}{$(3)$} & \multicolumn{1}{c}{$(4)$} \\
\hline Casualties, district & 14.25 & -12.92 & 177.8 & 157.0 \\
& $(34.69)$ & $(31.65)$ & $(124.0)$ & $(116.6)$ \\
Opium production, lagged & & $0.0506^{* *}$ & & 0.0230 \\
& & $(0.0235)$ & & $(0.0147)$ \\
Constant & $29.61^{* *}$ & $15.85^{*}$ & $25.64^{* *}$ & $16.21^{*}$ \\
& $(10.95)$ & $(8.557)$ & $(9.729)$ & $(9.417)$ \\
\hline Year & 2006 & 2006 & 2007 & 2007 \\
$\mathrm{R}^{2}$ & 0.001 & 0.075 & 0.083 & 0.111 \\
$\mathrm{~N}$ & 329 & 329 & 329 & 329 \\
\hline
\end{tabular}

Notes: Contemporaneous correlation between the area of opium eradicated and Western combat casualties. Both eradicated area and casualties are measured on the district level.

Standard errors are clustered on province-year

not reported with a sufficiently precise location to code their district. These are coded at the province level, so we have somewhat richer data on the province level.

The casualties data are very skewed, mostly since in one encounter there may be several Western casualties. We have therefore chosen to focus on a dummy for whether there were casualties or not in a given area. ${ }^{19}$ The reason for this is twofold. First, as we do not observe the exact location of death for all the casualties in our data set, focusing on a dummy for conflict minimizes measurement error if the reporting of the exact location is correlated with other characteristics of the area where the conflict took place. Second, it is not obvious that the number of casualties in an area is a good indicator of the seriousness of the conflict in that area. An illustrating example is a shot-down helicopter: This causes a large number of casualties, but the number of casualties does not necessarily indicate that the conflict is more serious than a single solders dying on the ground while fighting. The localization of districts where Western casualties have been reported and the average measured production of opium is shown in Figure 3.

Opium production is based on data from the United Nations Office on Drugs and Crime (UNODC, 2007), that has surveyed opium production in Afghanistan since 1994. Their approach was initially based on surveying opium production in a number of villages and then aggregating. From 2002, parts of the data are instead based on satellite imagery, using differences in spectral reflectance of different crops to identify the area under opium cultivation. This is combined with annual field surveys to determine yields. See UNODC (2007) for further details of the survey methodology.

We also add data on monthly precipitation by district to be used as an instrument for opium production. These data are drawn from the Global Precipitation Climatology Project One-Degree Daily Precipitation Data Set, ${ }^{20}$ that provides data on daily precipitation on a $1 \times 1$ degree level. The observations are first interpolated by kriging, ${ }^{21}$ and averages are then taken for each district.

\footnotetext{
${ }^{19}$ Using the actual number of casualties gives similar results. The exception is the Granger test in Table 5, where some of the standard errors increase somewhat.

${ }^{20}$ Available from http://www1.ncdc.noaa.gov/pub/data/gpcp/1dd/

${ }^{21}$ Using a spherical semivariogram. For details on kriging, see e.g. Chilès and Delfiner (1999)
} 


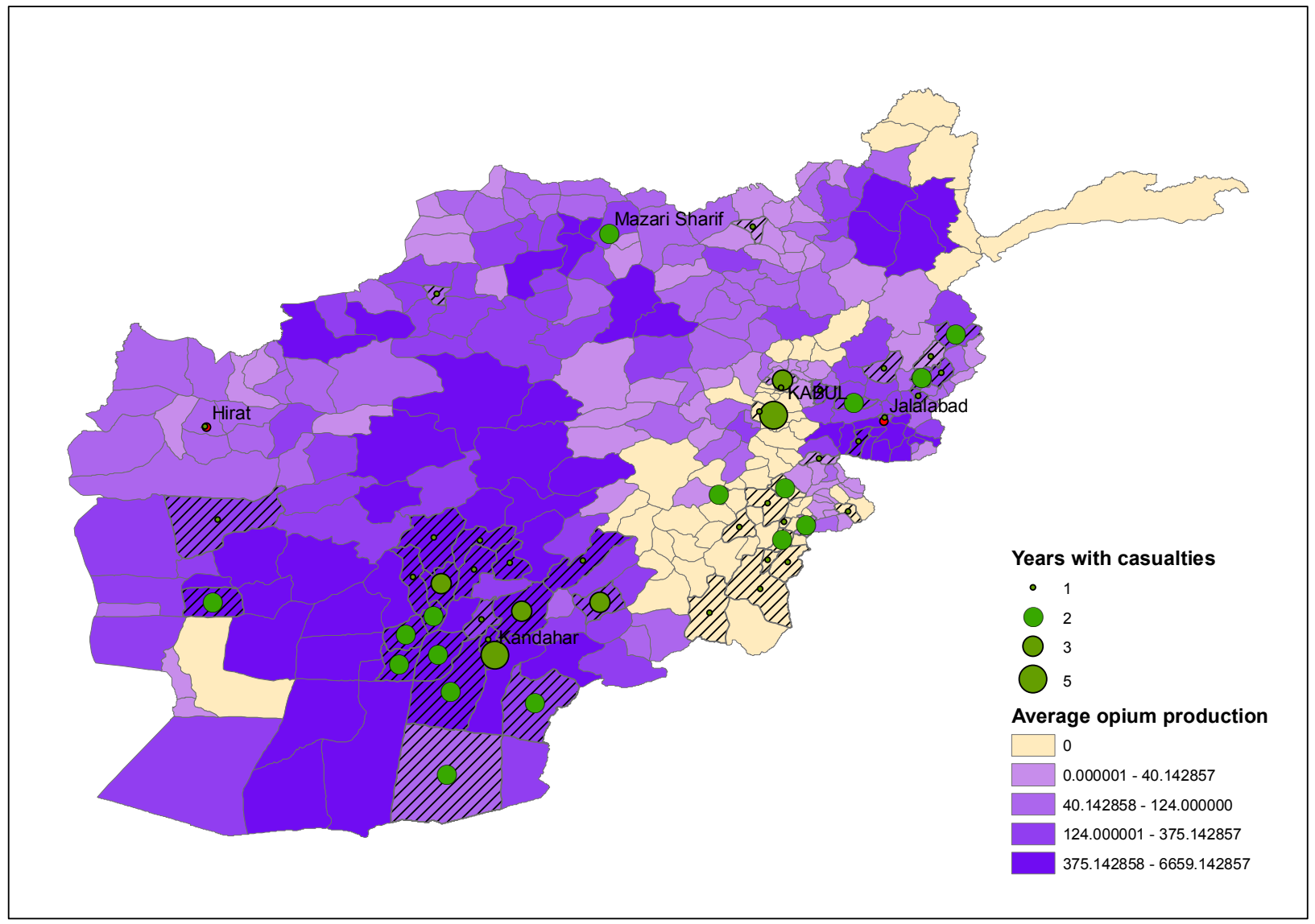

Note: District with fighting in at least one year are hatched.

\subsection{Findings}

In this section we provide our main estimates of the effect of (violent) conflict on subsequent opium production. The core results are shown in Table 3, which shows the results of regressing opium production on contemporaneous and lagged conflict with and without one- and two-way fixed effects. From Figure 2, it is clear that spurious results may arise if we do not take into account the trending in the level of both conflict and opium production. Consequently, most of our specifications include period dummies, which also accounts for changes in national and international policies, world market prices of opium, etc. We also control for district fixed effects, so variables such as the quality of the soil, ethnicity, former Taliban control and so do not drive the results.

The strongest test of our hypothesis is Column (6) of Table 3, where we estimate a strong and highly significant effect of lagged conflict on subsequent opium production at the district level, even after controlling for district and year fixed effects and contemporaneous conflicts. It is important to note that the identification in this table is based on two-way fixed effects, i.e. we assume that, conditional on the other right-hand-side variables and the fixed effects, the placement of the soldiers is exogenous to opium production. We have argued that this is a reasonable assumption in Section 4.1, based on official and unofficial US and NATO statements and the fact that eradication measures are uncorrelated with Western casualties. The rest of this section provides tests dedicated to checking whether the estimated relationships in Table 3 are causal. The estimated relationships in Table 3 passes all these test by a clear margin, and together these findings clearly show that there is a causal link from conflict to poppy cultivation. 
Table 3: Effects of Western combat casualties on opium production

\begin{tabular}{lrrrrrr}
\hline & \multicolumn{1}{c}{$(1)$} & $(2)$ & $(3)$ & $(4)$ & $(5)$ & \multicolumn{1}{c}{$(6)$} \\
\hline Casualties, district & $969.6^{*}$ & & & & & $565.2^{*}$ \\
& $(519.6)$ & & & & & $(305.1)$ \\
Casualties, district lagged & & $771.1^{* *}$ & & $490.8^{* *}$ & $368.3^{* * *}$ & $392.8^{* * *}$ \\
& & $(351.2)$ & & $(197.6)$ & $(141.5)$ & $(144.6)$ \\
Casualties, district two lags & & & 229.7 & & & -119.7 \\
& & & $(231.2)$ & & & $(314.2)$ \\
\hline District FE & No & No & No & Yes & Yes & Yes \\
Year FE & No & No & No & No & Yes & Yes \\
$\mathrm{R}^{2}$ & 0.028 & 0.011 & 0.001 & 0.007 & 0.034 & 0.040 \\
$\mathrm{~N}$ & 2303 & 1974 & 1645 & 1974 & 1974 & 1645 \\
\hline
\end{tabular}

Notes: Effects of contemporaneous and lagged Western combat casualties on opium production (2001-2007). Casualties on district level.

Standard errors are clustered on province-year

\section{District level estimates}

Table 3 shows results from regressions at the district level. Our claim is that conflicts stimulate poppy cultivation. Column (1) shows that there is a strong, positive, and significant contemporaneous correlation between casualties and opium production. However, as the planting season starts in October (UNODC, 2003, p. 31), one-year lagged effects of casualties on opium production seem to be a better test of our hypothesis of a positive relationship between conflict and opium production. From Column (2) we see that there is a strong and positive effect of one-year lagged casualties on opium production, and this holds even when we control for district fixed effects (Column (4)), year and district fixed effects (two-way fixed effects, Column (5)), and twoway fixed effects together with contemporaneous and two-year lagged casualties (Column (6)). The estimated coefficients are large. Using specification (5), where we have the lowest estimate, going from no conflict to conflict is estimated to lead to an increase in the area under cultivation of 368.3 hectares. This area on average produces about 14.7 metric tonnes of dry opium, which can be transformed into about 1.2 metric tonnes of heroin or more then six million user doses of $200 \mathrm{mg} .{ }^{22}$ Another way to grasp the magnitude is that it is 1.56 times the median production of opium producing districts. Also note that the value of the estimated parameter of lagged conflict on opium production has almost the same numerical value in columns (4), (5), and (6), i.e. it seems to be very robust to different specifications. Again, these regressions control for everything that is constant at the district level, so it is not differences in levels across different districts that are generating the results. The positive relationship holds also for two-year lags, but here the effect is not statistically significant, see column (3).

\section{Which way does the causality go?}

A sharp test of the direction of causality is a comparison of the association between conflict and opium production during and directly after the planting season. The reason for this being a sharp test of our hypothesis, is that if our hypothesis is correct, there should be a discontinuity at the end of the planting season: conflict during the planting season should have a strong effect

\footnotetext{
${ }^{22}$ One $\mathrm{kg}$ of heroin requires $11-13 \mathrm{~kg}$ of opium(UNODC, 2003, p. 133). Doses vary a lot, from 1-5mg for initial doses to about $1 \mathrm{~g}$ for very experienced users. The study by Gschwend et al. (2004) reports an average daily consumption of $474 \mathrm{mg}$ among heavy users.
} 
on opium production, whereas conflict once the opium has been planted should have no effect. All over Afghanistan, opium is planted between September and November. Planting later than this significantly reduces yields, and is therefore extremely uncommon (UNODC, 2003, p. 31). This is also confirmed by agronomic studies; although the optimal planting date depends on agro-climatic conditions, germination is hindered in early sowing and late sowing leads to too fast maturity and reduced opium yields (Yadav, 1983, p. 86). By planting 10 days after the optimal day, yields are reduced by 13 percent (ibid.).

Any effect from opium production to conflict, however, should be independent of whether we are in the planting season or not. If the battles were over the opium territory, warlords would be equally interested in fighting back in January as in October. For this reason we can threat conflict in the period after the planting season as a placebo, enabling us to identify the direction of causality between conflict and opium production.

In Table 4, Columns (1) (without year fixed effects) and (6) (with year fixed effects) show estimates from the same regressions as in Table 3, but now including only casualties from the planting season. Columns (2) and (7) (without year fixed effects) and (3) and (8) (with year fixed effects) measure the effect in the control group, i.e. the effect of conflict directly after the planting season has ended. Columns (2) and (7) include casualties from a period equally long as the planting season variable. There is less conflict in this period than in September to November; the mean of the conflict variables is reported at the bottom of the table. Therefore, we also try the same experiment using a control period that contains approximately the same level of conflict, shown in Columns (3) and (8). From the Table we see that there is a sharp difference in the estimated effect of conflict on opium production in the planting season relative to directly after, the estimated effect in the planting season is strongly significant and in numerical value somewhat above what we found in Table 3 . The effect of casualties directly after the planting season is much smaller in numerical value, and it is far from significant. We have also tried including both casualties in and out of the planting season, see columns (4) and (5) (without year fixed effects) and (9) and (10) (with year fixed effects). The results are again exactly the same- only conflict during the planting season induces opium production.

The same direction of causality is confirmed in Table 5, which shows the results from a Granger causality test. The two columns shows the results from regressions of current opium production and conflict on one-year lags of the two. Again we see that lagged casualties have a significant effect on opium production, whereas lagged opium production has no significant effect on conflict. We can conclude that conflict Granger-causes opium production. In other words, we can reject that the correlation we observe between conflict and subsequent opium production is caused by Western soldiers going into areas where they have learned that there is a lot of opium production combined with opium production being positively correlated over time.

\section{Where is the effect strongest?}

Our mechanism should be stronger in areas in which the government has less control and where it is easier to extract opium profits, i.e. areas in which governmental law enforcement is weak. In terms of our model, such weak law enforcement is captured by a high level of $\theta$. The combination of bad institutions and "lootable" resource rents is emphasized as a special bad case in the resource curse literature (Mehlum et al., 2006).

To demonstrate that conflicts is particularly harmful where governmental law enforcement is weak, we proxy bad institutions with (altitude-weighted) distance to Kabul. Law enforcement is clearly best in Kabul, the area in which the government has full control and were there is a strong presence of Western forces, and declining in the distance from the capital. This is of course an imperfect proxy of government control, but since there is no reason to believe that 


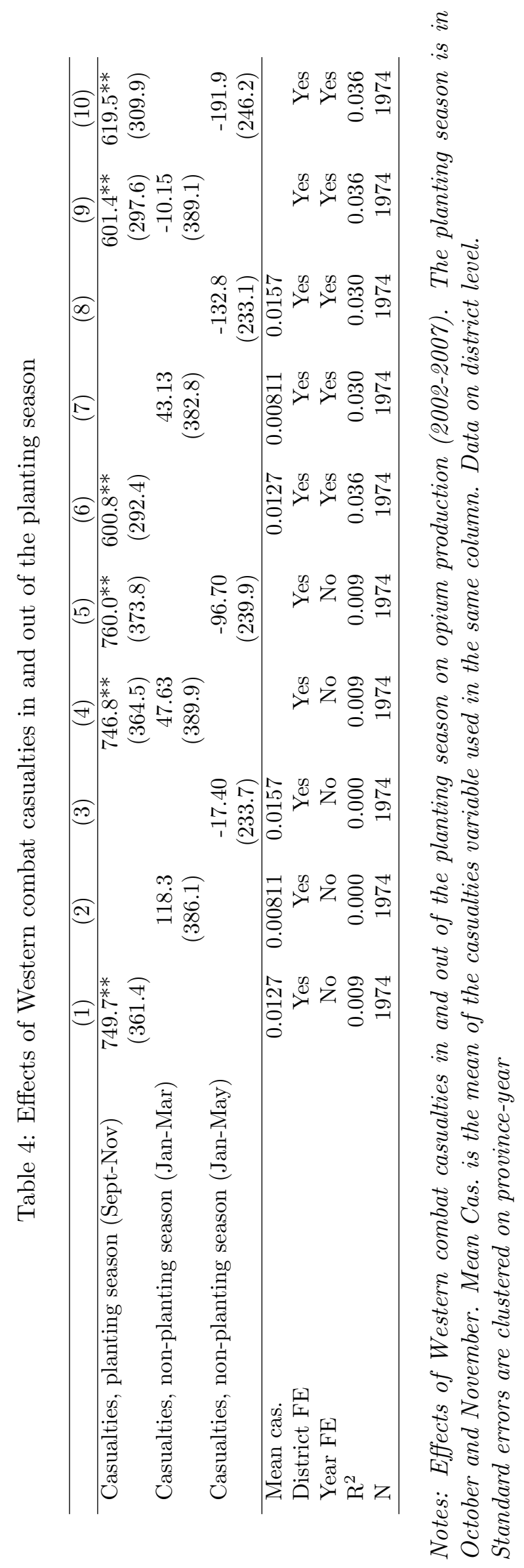


Table 5: Granger causality test

\begin{tabular}{lcc}
\hline & Opium prod. & Casualties \\
\hline Opium production, lagged & $0.643^{* *}$ & 0.0000166 \\
& $(0.250)$ & $(0.0000121)$ \\
Casualties, district lagged & $461.8^{*}$ & $-0.282^{* * *}$ \\
& $(261.3)$ & $(0.109)$ \\
\hline$\chi^{2}$ & 3.123 & 1.866 \\
p-value & 0.077 & 0.172 \\
District FE & Yes & Yes \\
Year FE & Yes & Yes \\
$\mathrm{N}$ & 1645 & 1645 \\
\hline
\end{tabular}

Notes: Effects of lagged Western combat casualties and opium production on current Western casualties and opium production. Casualties on district level. The equations are estimated using the Arellano and Bond (1991) procedure, since they contain a lagged endogenous variable on the right hand side. $\chi^{2}$ is the test statistic of a $\chi^{2}$ test of lagged casualties being different from zero in column (1) and of lagged opium production being different from zero in column (2). p-value is the p-value of this test.

Robust standard errors in parentheses.

the measurement error introduced is non-classical, the estimates can be seen as lower bounds on the true values. In Table 6 we study the interaction of fighting with the distance to Kabul. The effect of casualties is stronger further away from Kabul. With an even split between the half of the districts closest to and furthest away from Kabul, only the furthest half show any relationship between fighting and opium production. That conflicts stimulate opium production in areas where law enforcement is weak, is clearly in line with our theory.

\section{Conflict or just the presence of Western soldiers?}

One objection that could be raised to the results reported above is that Western casualties in a district may be a measure of the presence of Western soldiers rather than the occurrence of fighting. One mechanism that could generate the positive correlation in Table 3 could be the following: When Western forces have control over an area, it is easier to smuggle drugs out since these forces have an explicit policy of not intervening in drugs trade (see quotes above). To control for this, we separate between the effects of hostile and non-hostile Western casualties. Non-hostile casualties are events such as car accidents or illness, and indicate the presence of Western soldiers in a district without indicating occurrences of fighting. We want to test whether both hostile and non-hostile casualties have an effect on opium production versus the alternative of only hostile casualties having an effect.

Table 7 reports the results from this analysis. The coefficients on hostile casualties are about the same as in Table 3. The coefficients on non-hostile casualties are negative or insignificant, indicating that there is no effect on opium production from the presence of Western soldiers; only conflict increases subsequent opium production. Also note that the numerical value of the estimated effect of conflict on opium production is almost the same in Table 7 as in Table 3. In the specifications where the coefficients on non-hostile casualties are significant, they are negative. This may indicate that if there are non-hostile casualties in an area, the area has stronger law enforcement and hence less opium production. Thus, we find no support for the hypothesis that there will be an increase in opium production in areas controlled by Western forces due to safer smuggling routes. 


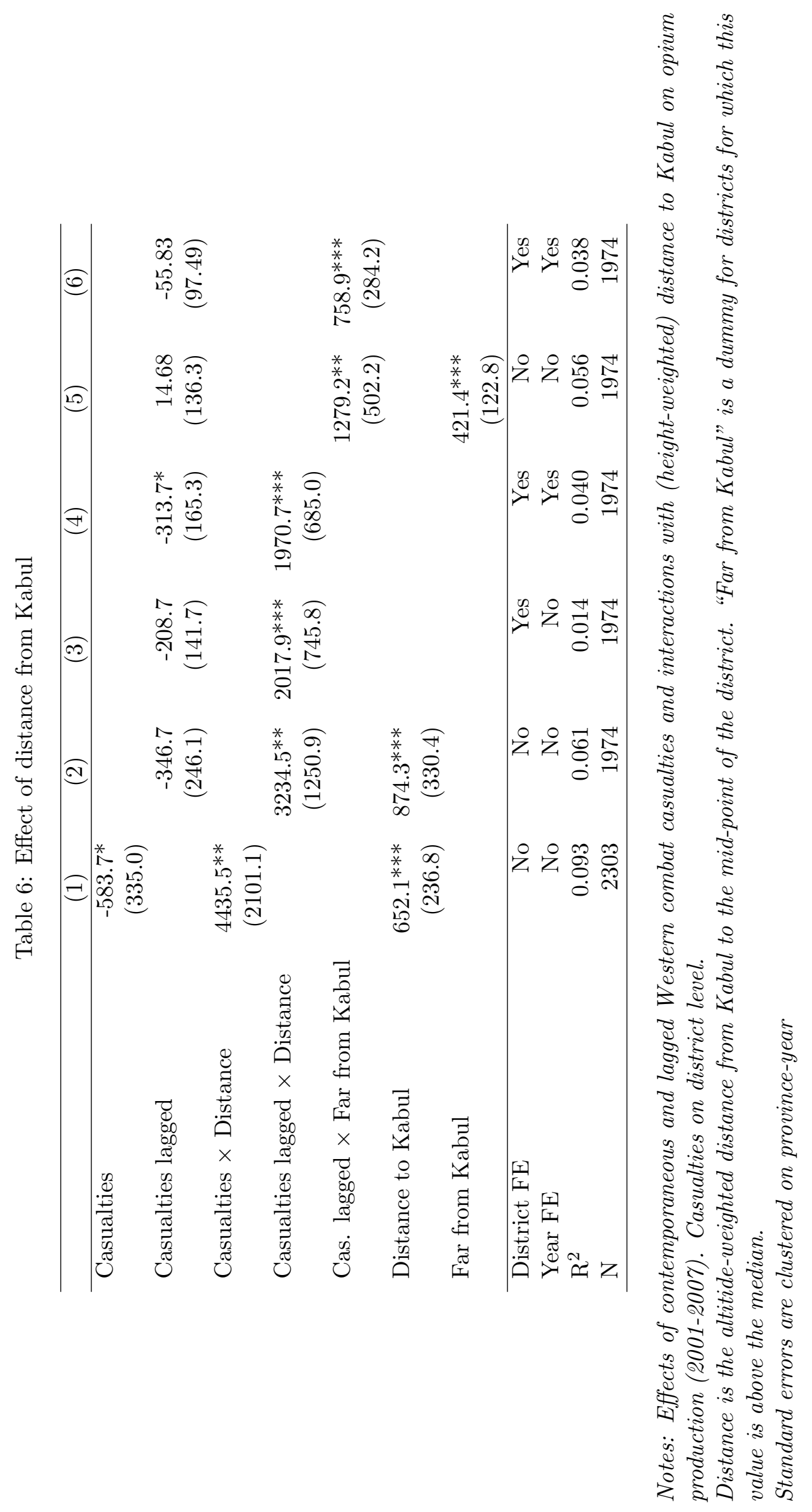


Table 7: Effects of Western combat and non-hostile casualties on opium production

\begin{tabular}{lrrrrrr}
\hline & \multicolumn{1}{c}{$(1)$} & $(2)$ & $(3)$ & $(4)$ & $(5)$ & \multicolumn{1}{c}{$(6)$} \\
\hline Hostile casualties & $1104.4^{*}$ & & & & & $569.1^{*}$ \\
& $(571.4)$ & & & & & $(303.3)$ \\
Hostile casualties, lagged & & $873.9^{* *}$ & & $447.9^{* *}$ & $340.8^{* *}$ & $434.0^{* * *}$ \\
& & $(371.3)$ & & $(185.3)$ & $(138.4)$ & $(163.0)$ \\
Hostile casualties, two lags & & & 335.2 & & & -63.55 \\
& & & $(267.8)$ & & & $(323.3)$ \\
Non-hostile casualties & $-555.0^{* *}$ & & & & & -29.88 \\
& $(244.7)$ & & & & & $(129.8)$ \\
Non-hostile casualties, lagged & & $-358.6^{*}$ & & 288.8 & 191.6 & 103.3 \\
& & $(204.0)$ & & $(221.0)$ & $(210.5)$ & $(180.8)$ \\
Non-hostile casualties, two lags & & & $-348.0^{*}$ & & & -327.4 \\
& & & $(203.0)$ & & & $(205.5)$ \\
\hline District FE & No & No & No & Yes & Yes & Yes \\
Year FE & No & No & No & No & Yes & Yes \\
$\mathrm{R}^{2}$ & 0.031 & 0.012 & 0.001 & 0.008 & 0.034 & 0.041 \\
$\mathrm{~N}$ & 2303 & 1974 & 1645 & 1974 & 1974 & 1645 \\
\hline
\end{tabular}

Notes: Effects of contemporaneous and lagged Western combat and non-hostile casualties on opium production (2001-2007). Casualties on district level.

Standard errors are clustered on province-year

\subsection{Robustness}

\section{Province level data}

Table 8 shows the same regressions as in Table 3, but with province level data on casualties. These estimates benefit from the somewhat richer conflict data we have on the province level as some incidents can only be attributed to the province and not the district, and can also take into account cross-district spillover effects. Opium production is still on district level. Again we find strong and positive effects of casualties on opium production, however, the estimates are somewhat less robust to the inclusion of two-way fixed effects than the ones using district level data. It is important to note that, despite having more data on conflict on province level, the 32 provinces $^{23}$ in Afghanistan are large, with an average of about 10 districts per province, hence we lose a lot of information by exploiting only the province part of the casualties data.

\section{Correcting simultaneity bias by instrumenting}

Another way to tackle the possibility that conflict and opium production are simultaneously determined is through instrumental variables. To formalize, we say that

$$
\begin{aligned}
C_{i t} & =a_{i}+b O_{i t}+d^{\prime} Z_{i t}+\varepsilon_{i t}^{1} \\
O_{i t} & =\alpha_{i}+\beta C_{i t}+\delta^{\prime} Z_{i t}+\phi^{\prime} W_{i t}+\varepsilon_{i t}^{2}
\end{aligned}
$$

where $C_{i t}$ is conflict, $O_{i t}$ is opium production, $Z_{i t}$ is a vector of covariates common to the two equations, and $W_{i t}$ are covariates unique to equation (5b). Notice that we have imposed an

\footnotetext{
${ }^{23}$ After a redistricting, there are now 34 provinces. We use the old definitions to maintain continuity in the opium production data.
} 
Table 8: Effects of Western combat casualties on opium production. Casualties measured at the province level

\begin{tabular}{lrrrrrr}
\hline & $(1)$ & $(2)$ & $(3)$ & $(4)$ & $(5)$ & \multicolumn{1}{c}{$(6)$} \\
\hline Casualties, province & $318.1^{* *}$ & & & & & -79.81 \\
& $(159.9)$ & & & & & $(115.8)$ \\
Casualties, province lagged & & $387.7^{*}$ & & $282.2^{* *}$ & 159.6 & 193.4 \\
& & $(212.5)$ & & $(138.4)$ & $(116.7)$ & $(149.7)$ \\
Casualties, province two lags & & & 355.6 & & & 158.6 \\
& & & $(281.1)$ & & & $(169.3)$ \\
\hline District FE & No & No & No & Yes & Yes & Yes \\
Year FE & No & No & No & No & Yes & Yes \\
$\mathrm{R}^{2}$ & 0.019 & 0.023 & 0.016 & 0.016 & 0.034 & 0.033 \\
$\mathrm{~N}$ & 2303 & 1974 & 1645 & 1974 & 1974 & 1645 \\
\hline
\end{tabular}

Notes: Effects of contemporaneous and lagged Western combat casualties on opium production (2001-2007). Casualties on province level, opium production on district level.

Standard errors are clustered on province-year

exclusion restriction, namely that $W_{i t}$ only appears in the equation for opium production. This allow us to use $W_{i t}$ as instruments for $O_{i t}$, and hence to consistently estimate $b$ in equation (5a). However, we are mostly interested in estimating $\beta$, the coefficient on conflict in the equation for opium production. The standard order condition tells us that it is not possible to identify $\beta$ without either using an instrument for conflict in equation (5b) or imposing an additional restriction. As it seems to be extremely hard to find a valid (ordinary) instrument for conflict we follow the latter approach, by imposing the restriction that the covariance between $\varepsilon_{i t}^{1}$ and $\varepsilon_{i t}^{2}$ is zero. This essentially requires that there are no common omitted variables to the two equations. Although this is a strong assumption, the fact that we use two-way fixed effects reduces the problem considerably. Under this restriction, Hausman and Taylor (1983) have shown that a valid instrument for $C_{i t}$ in equation (5b) is the estimated residuals $\hat{\varepsilon}_{i t}^{1}$ obtained from a 2SLS regression on equation (5a) with $W_{i t}$ as instruments for opium. Due to the restriction on the covariance matrix of the errors, $\widehat{\varepsilon}_{i t}^{1}$ will be correlated with $C_{i t}$ (from equation (5a)), but will be uncorrelated with $\varepsilon_{i t}^{2}$, i.e. $\widehat{\varepsilon}_{i t}^{1}$ satisfies the standard conditions for being a valid instrumental variable.

A common instrument for agricultural production in poor countries is deviation from trend in rainfall (see among others Miguel et al., 2004; Paxson, 1992; Hidalgo et al., forth.). Even though opium is more drought-resistant than wheat, poppy cultivation, as with the cultivation of all other crops, requires some water during the growth cycle (Kapoor, 1995, Ch. 4). Therefore, rainfall is likely to be correlated with opium production. Furthermore, it seems unlikely that rainfall should have any direct impact on western hostile casualties, justifying the exclusion restriction imposed in equation (5a). The reason for making the last claim is that conflict is here measured as a dummy for whether there have been hostile casualties in a district on a yearly basis. Even though deviations from normal rainfall such as snow storms may influence the timing of the Western forces' operations somewhat, it seems unlikely that this should have any effect on whether the operations are implemented or not. Thus, it seems unlikely that rainfall affects conflict directly in our setting.

Table 9 shows results from the instrumental variables regression. $Z_{i t}$ contains district and year fixed effects and $W_{i t}$ contains the rainfall variables described in the data section. In columns (1) and (2) we report standard OLS-estimates for the two equations. We see that both $\hat{b}$ and $\hat{\beta}$ 
are positive and highly significant. In columns (3) and (4) we control for the simultaneity bias by estimating the parameters using the Hausman and Taylor (1983) approach. We here see that the effect of conflict on opium $(\hat{\beta})$ is still highly significant, and in numerical value almost equal to the ones presented in Table 3 . The estimated $\hat{b}$, however, is diminished by a ten-fold, and is no longer significant. This clearly corroborates the findings above.

\section{An artifact of the change in measurement technology?}

Since 2002, the surveying of opium production in some of the districts has been conducted by satellite imagery. Although it seems that this is mostly due to increased efficiency in the data collection, the initial explanation was that the level of conflict in some of the provinces was so high that is was impossible to survey the production in these areas using on-the-ground surveyors. As the measurement technology may influence the reported opium production and be correlated with conflict, we run the same regressions as in Table 3, while also controlling for satellite measurement. The results can be found in Table 10. Column (1) is a difference in differences estimation of the impact of measurement by satellite on the measured opium production. It seems that using satellite measurement tends to increase the measured area under opium production. Still, the effect of conflict on opium production, reported in Columns (2) to (7), remains very close to those reported in Table 3 , so our findings are not driven by a spurious effect from the measurement technology. As the satellite variable is highly endogenous - correlated with conflict since this was the original reason for using satellite, and possibly correlated with opium production since the production estimates are based on a different measurement technology - we did not include satellite as a separate control in the regressions reported above.

Another worry concerning the measurement of opium production is that the number of districts surveyed has been increasing over time, especially during the 1990's. Apparently, at least in the beginning, UNODC only surveyed districts in which they believed there was opium production. To ensure that the expansion in the number of districts surveyed does not affect our estimates, we have run the same regressions as in Table 3 using only districts that had positive opium production in at least one year during the 1990's. The results are literally unchanged, but as the sample size is reduced, the standard errors increase somewhat (results not shown, but available on request).

\section{Caused by price movements?}

We have not taken price changes into account in the previous estimations. It seems reasonable to think that the decision to produce opium also depend on the price a farmer gets for his opium. However, as prices also depend on supply, this is a classical case of an endogenous variable. One could imagine mechanisms by which the results discussed so far could be driven by price movements. UNODC (various issues) has collected opium prices from household surveys, although they are only broken down at the level of six regions. The data are shown if Figure 4. It is seen that the geographical variation is modest, and that most of the variation comes from time series variation. Hence the effect of prices is largely picked up by the year dummies in the preceding estimation. If prices are included in similar analyzes, the conclusions are unchanged, and prices have no significant relationship with opium production. ${ }^{24}$ In addition, from Figure 4 we see that farm gate prices have plunged in the period from 2004 and onward, indicating that they cannot be an important explanation of the huge increase in opium production. It seems more reasonable that the recent increase has pushed prices down, if anything.

\footnotetext{
${ }^{24}$ Estimates not shown but available upon request
} 


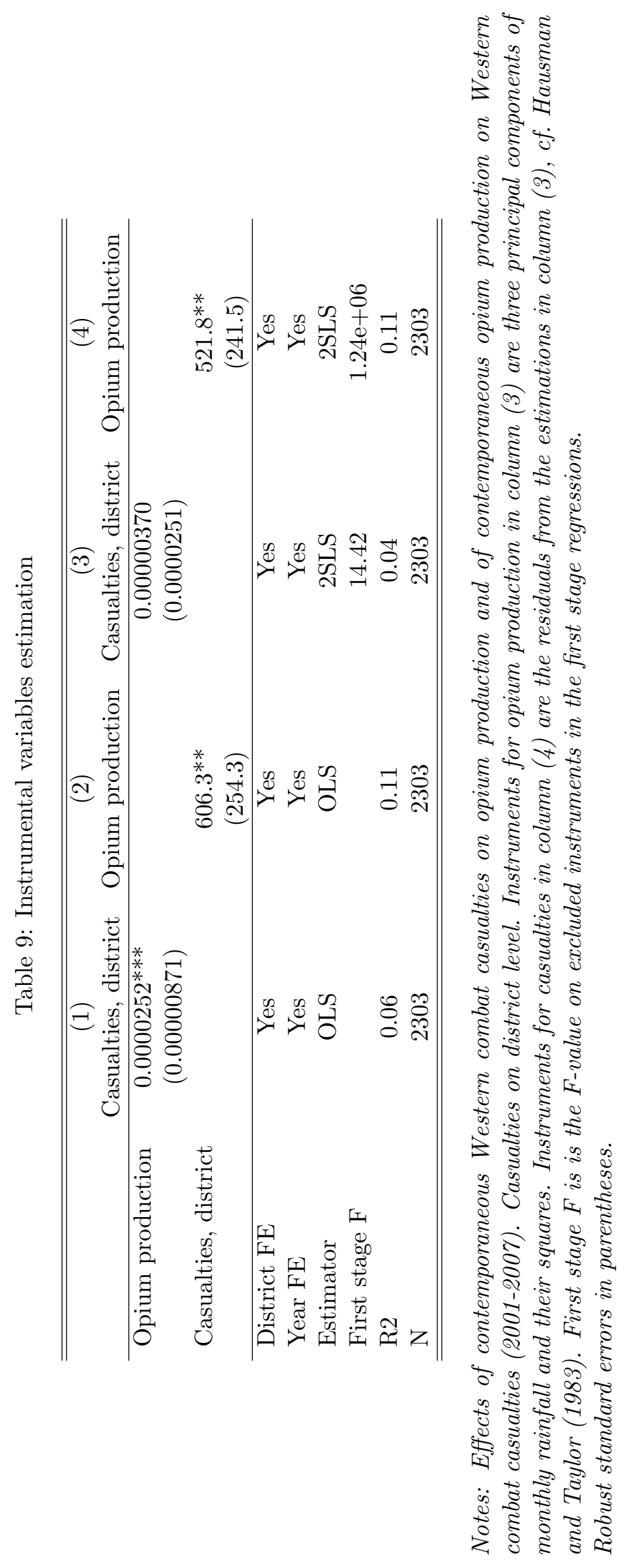




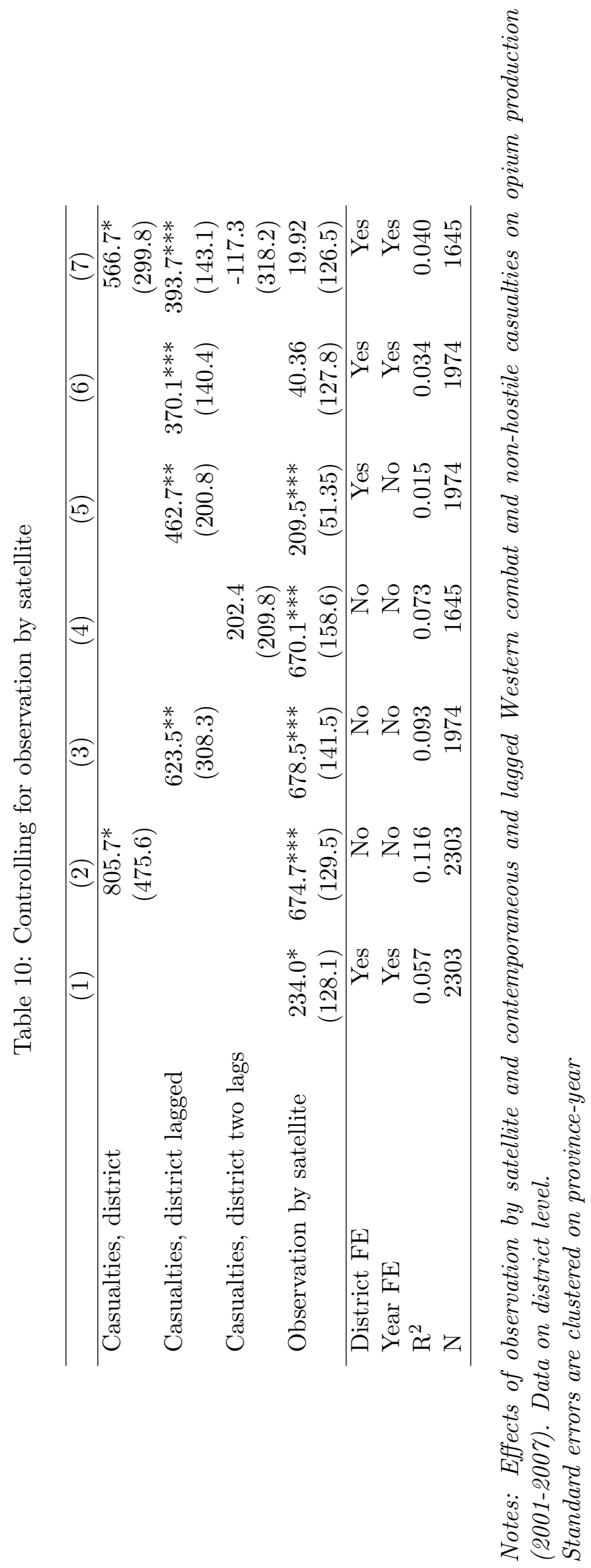


Figure 4: Farm gate prices of opium

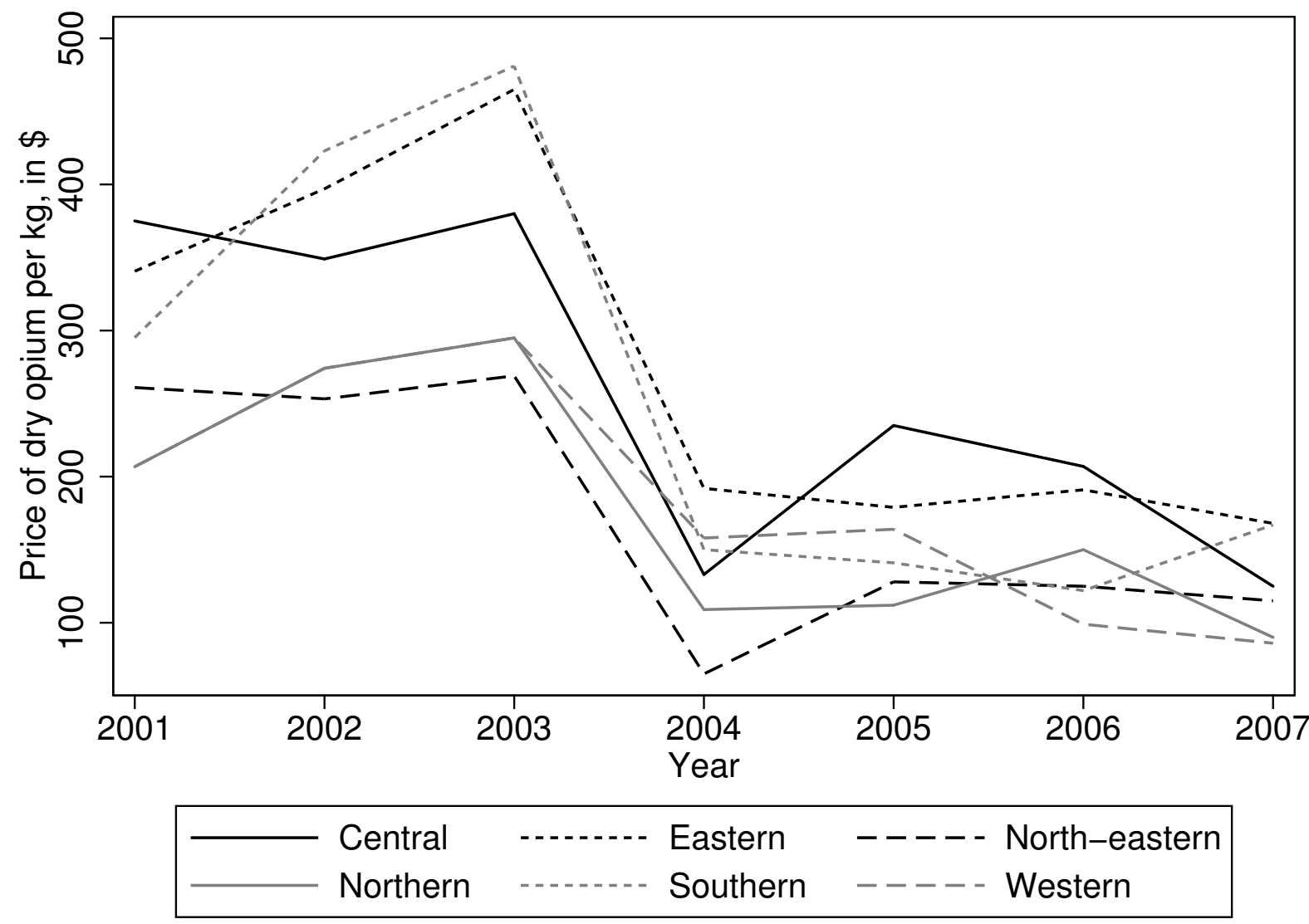

Note: The graph shows the estimates farm gate value of opium production by year, broken down by six broad regions.

\section{Driven by a general increase in farming activities?}

One final worry is that the relationship we observe between conflict and opium production reflects a general increase in farming activities, due for example to an influx of returnees causing more land scarcity, which in turn increases opium production. To test this we have collected data on wheat production, made available by FAO. Unfortunately wheat data are only available on province level. Running the two-way fixed effects model in Table 3 with wheat production rather than opium production as the dependent variable, we find no significant relationship between the two variables (results not reported). However, we also get insignificant results when running opium production on casualties on province level after taking out two-way fixed effects. Province level data seems to contain too little geographical information to be able to estimate the effect of conflict precisely (see also the discussion following Table 8). There is almost no correlation between wheat production and opium production, ${ }^{25}$ however, indicating that it does not seem to be the case that the relationship we observe is due to a general increase in farming activities.

\footnotetext{
${ }^{25}$ The correlation coefficient between wheat and opium production on pooled data is 0.02 . Taking out province fixed effects, the partial correlation coefficient is 0.01 . Taking out year fixed effects in addition, reduces the coefficient to -0.05 .
} 


\section{Conclusion}

While most conflict studies focus on the behavior of the fighting contestants, we focus more on the behavior of local leaders and the people living in the conflict areas. Afghanistan is a good example of how rising conflicts change their incentives and behaviors. The changes may come about because conflicts are destructive, destroying physical capital and infrastructure, and because conflicts are creative, opening up new opportunities for economic activities. Opium production in Afghanistan benefits on both fronts.

Opium production is less hurt than other activities by the local destructions that conflicts cause; it is less dependent on infrastructure such as roads and irrigation systems and it becomes more socially feasible as conflicts alter local power and moral norms. The new and more flexible interpretations of "legality," combined with the decline in legal opportunities, make opium production tempting for many local people who otherwise would be more reluctant to be involved.

We capture some of this in a simple model which is used as a motivation for an empirical assessment of how conflicts induce opium production in Afghanistan. We find strong support for our main mechanism. Exploiting a unique data set, we show that Western hostile casualties, our proxy for conflict, have a strong impact on subsequent local opium production. This proxy is shown to be exogenous to opium, both by statements from US and NATO forces claiming that they are not involved in military actions against opium producers, and by the zero correlation between eradication of opium production and Western casualties.

If it was the case that the warlords only fought back in areas with much opium, the positive correlation between casualties and subsequent opium production could still be observed even with the placement of the soldiers being random. But there is no support for this story about defending opium in particular, since we show that hostile casualties only have an effect prior to the planting season. If the battles were over the opium territory, warlords would be equally interested in fighting back in January as in October. We therefore conclude that the dramatic rise in Afghan poppy cultivation in the period 2002-2007 is a direct consequence of the rising violent conflicts in the country. This is why we claim that narcotics production is conflict-induced.

We believe that there also is a strong drugs-for-arms mechanism at work in Afghanistan, although this is not the topic of our paper. Our focus on those conflicts that are exogenous to opium production enables us to identify the link from conflict to opium production. Due to this exogeneity, however, we are unable to quantify the traditional drugs-for-arms mechanism with our data. If both conflict-induced narcotics production and drugs-for-arms mechanisms are at work at the same time, the combination of the two may create a vicious circle: More intense conflicts stimulate more opium production enabling warlords, militia leaders, and other strongmen to finance military campaigns escalating the conflicts further.

Clearly, opium production creates profit opportunities for local strongmen and warlords. Large sums of money must be involved from a trade that covers 90 percent of the world's illegal consumption of opium. This speaks to the current debate on how Afghanistan should treat warlords and drug traffickers who presently profit on the drug trade. ${ }^{26}$ When eradication teams moved into the Helmand province, for instance, the governor announced an amnesty for drug traffickers: "We as a government will provide the opportunity to use their money for the national benefit $[\ldots]$ they must invest in industries. They must invest in construction companies" (quoted in MacDonald (2007, p. 97)). We do not know whether amnesty is a good solution to Afghanistan's opium related development crisis. What we do claim, however, is that the local insecurity in the country has detrimental effects on local investments, which in turn induce even higher opium production.

\footnotetext{
${ }^{26}$ See Grossman and Mejía (2008) for an analysis of the effectiveness of anti-drug policies in the case of Colombia.
} 


\section{References}

Angrist, Joshua D. and Adriana D. Kugler, "Rural windfall or new resource curse? Coca, income and civil conflict in Colombia," Review of Economics and Statistics, 2008, 90, 191-215.

Arellano, Manuel and Stephen Bond, "Some Tests of Specification for Panel Data: Monte Carlo Evidence and an Application to Employment Equations," Review of Economic Studies, April 1991, 58 (2), 277-97.

Barth, Fredrik, Afghanistan og Taliban, Oslo: Pax Forlag AS, 2008. (in Norwegian).

Berdal, Mats and David Malone, eds, Greed and Grievance: Economic Agendas in Civil Wars, Boulder: Lynne Rienner Publishers, 2000.

Booth, Martin, Opium. A History, London: Simon\&Schuster, 1996.

CCINC, "World Opium Survey 1972," 1972. Washington, DC: US Cabinet Committee on International Narcotics Control.

Chilès, Jean-Paul and Pierre Delfiner, Geostatistics. Modeling Spatial Uncertainty, New York: Wiley, 1999.

Cornell, Svante E., "The Interaction of Narcotics and Conflict," Journal of Peace Research, 2005, 42, 751-60.

Díaz, Ana María and Fabio Sánches, "A Geography of Illicit Crops (Coca Leaf) and Armed Conflict in Colombia," Crisis States Programme Working Paper no. 472004.

Dube, Oeindrila and Juan Vargas, "Commodity Price Shocks and Civil Conflict: Evidence from Colombia," 2008. Working paper, Harvard.

Farrell, Graham and John Thorne, "Where have all the flowers gone?: evaluation of the Taliban crackdown against opium poppy cultivation in Afghanistan," International Journal of Drug Policy, March 2005, 16 (2), 81-91.

Giustozzi, Antonio, War, Politics and Society in Afghanistan, 1978-1992, Washington, DC: Georgetown University Press, June 2000.

_, Koran, Kalashnikov and Laptop: The Neo-Taliban Insurgency in Afghanistan 2002-2007, London: C Hurst \& Co Publishers Ltd, October 2007.

Greenstone, Michael, "Is the "Surge" Working? Some New Facts," National Bureau of Economic Research Working Paper Series, October 2007, 13458.

Grossman, Herschel I. and Danial Mejía, "The war against drug producers," Economics of Governance, 2008, 9, 5-23.

Gschwend, Patrick, Jürgen Rehm, Richard Blättler, Thomas Steffen, André Seidenberg, Stephan Christen, Christoph Bürki, and Felix Gutzwiller, "Dosage Regimes in the Prescription of Heroin and Other Narcotics to Chronic Opioid Addicts in Switzerland - Swiss National Cohort Study," European Addiction Research, 2004, 10, 41-48.

Guidolin, Massimo and Eliana La Ferrara, "Diamonds Are Forever, Wars Are Not: Is Conflict Bad for Private Firms?," American Economic Review, December 2007, 97 (5), 19781993. 
Haq, Ikramul, "Pak-Afghan drug trade in historical perspective," Asian Survey, 1996, 36, 945-63.

Hausman, Jerry A. and William E. Taylor, "Identification in Linear Simultaneous Equations Models with Covariance Restrictions: An Instrumental Variables Interpretation," Econometrica, 1983, 51 (5), 1527-1549.

Hidalgo, F. Daniel, Suresh Naidu, Simeon Nichter, and Neal Richardson, "Occupational Choices: Economic Determinants of Land Invasions," The Review of Economics and Statistics, forth.

Independent, "Warlord: My encounter with Taliban mastermind," June 2008. 22.06.2008. Available at http://www.independent.co.uk/news/world/asia/ warlord-my-encounter-with-taliban-mastermind-851912.html.

Iyengar, Radha and Jonathan Monten, "Is There an "Emboldenment" Effect? Evidence from the Insurgency in Iraq," National Bureau of Economic Research Working Paper Series, March 2008, 13839.

Kaplan, Robert D., Soldiers of God: With Islamic Warriors in Afghanistan and Pakistan, New York: Vintage Books, 2001.

Kapoor, L. D., Opium Poppy: Botany, Chemistry, and Pharmacology, New York: Haworth Press, 1995.

Keen, David, "Incentives and Disincentives for Violence." In Berdal and Malone, eds (2000) chapter 2 .

Landes, David S., The Unbound Prometheus-Technological change and industrial development in Western Europe from 1750 to the present, London: Cambridge University Press, 1969.

MacDonald, David, Drugs in Afghanistan: Opium, Outlaws and Scorpion Tales, London: Pluto Press, February 2007.

Mansfield, David, "The Economic Superiority of Illicit Drug Production: Myth and Reality. Opium Poppy Cultivation in Afghanistan," August 2001. Paper prepared for the International Conference on Alternative Development in drug control and cooperation, Feldafing, September 7-12, 2002.

_, "What is Driving Opium Poppy Cultivation? Decision Making Amongst Opium Poppy Cultivators in Afghanistan in the 2003/4 Growing Season," in "Second Technical Conference on Drug Control Research" UNODC/ONDCP July 2004.

_, "What is Driving Opium Poppy Cultivation? The Pressures to Reduce Opium Poppy Cultivation in Afghanistan in the 2004/05 Growing Season," Technical Report, Afghan Drugs Inter Departmental Unit of the UK Government March 2005.

Martin, Edouard and Steven Symansky, "Macroeconomic Impact of the Drug Economy and Counter-Narcotics Efforts," in William A. Byrd and Doris Buddenberg, eds., Afghanistan's Drug Industry: Structure, Functioning, Dynamics, and Implications for Counter-Narcotics Policy, The World Bank, 2006, chapter 2.

McCoy, Alfred, The politics of heroin: CIA complicity in the global drug trade, New York: Lawrence Hill, 1991. 
Mehlum, Halvor, Karl Moene, and Ragnar Torvik, "Institutions and the Resource Curse," The Economic Journal, January 2006, 116 (508), 1-20.

Miguel, Edward, Shanker Satyanath, and Ernest Sergenti, "Economic Shocks and Civil Conflict: An Instrumental Variables Approach," Journal of Political Economy, 2004, 112, $725-53$.

Misra, Amalendu, Afghanistan: The Labyrinth of Violence, Cambridge: Polity, May 2004.

New York Times, "Poppy Fields Are Now a Front Line in Afghan War," 2007. 16.5.2007. Available at http://www.nytimes.com/2007/05/16/world/asia/16drugs.html.

Paxson, Christina H., "Using weather variability to estimate the response of savings to transitory income in Thailand," American Economic Review, 1992, 82, 15-33.

Rashid, Ahmed, Taliban: Militant Islam, Oil and Fundamentalism in Central Asia, New Haven: Yale University Press, March 2000.

Rubin, Barnett R., The Fragmentation of Afghanistan: State Formation and Collapse in the International System, Second Edition, New Haven: Yale University Press, March 2002.

Sachs, Jeffrey D. and Andrew M. Warner, "Natural Resource Abundance and Economic Growth," NBER Working Paper 5398 December 1995.

- and _, "Sources of Slow Growth in African Economies," Journal of African Economics, October 1997, 6 (3), 335-376.

_ and _, "The curse of natural resources," European Economic Review, May 2001, 45, 827838.

The Times, "Amid the thud of artillery, soldiers stormed into a Taleban stronghold," 2006. 14.09.2006. Available at http://www.timesonline.co.uk/tol/news/world/ article1073949.ece.

UNODC, "Opium Production Throughout The World," Bulletin on Narcotics, 1949, 1 (1), 6-38. Available at http://www.unodc.org/unodc/en/data-and-analysis/bulletin/ bulletin_1949-01-01_1_page005.html.

_. "The Opium Economy in Afghanistan-An International Problem," United Nations, Office on Drugs and Crime New York 2003.

_ , "Farmers Intentions Survey 2003/2004," United Nations, Office on Drugs and Crime Vienna February 2004.

_ , "Afghanistan Opium Survey 2006," United Nations, Office on Drugs and Crime Vienna October 2006.

_ , "Afghanistan Opium Survey 2007," United Nations, Office on Drugs and Crime Vienna October 2007.

_ , "World Drug Report 2008," United Nations, Office on Drugs and Crime Vienna 2008.

Willumsen, Fredrik, "Debt and poppy cultivation-Driving factors behind Afghan opium production," Master's thesis, University of Oslo November 2006.

Yadav, R. L., "Agronomical perspectives," in Akhtar Husain and J. R. Sharma, eds., The Opium Poppy, Lucknow, India: Central Institute of Medicinal \& Aromatic Plants, 1983, chapter 6 . 


\section{CESifo Working Paper Series}

for full list see www.cesifo-group.org/wp

(address: Poschingerstr. 5, 81679 Munich, Germany, office@cesifo.de)

2509 Louis Hotte and Stanley L. Winer, The Demands for Environmental Regulation and for Trade in the Presence of Private Mitigation, December 2008

2510 Konstantinos Angelopoulos, Jim Malley and Apostolis Philippopoulos, Welfare Implications of Public Education Spending Rules, December 2008

2511 Robert Orlowski and Regina T. Riphahn, The East German Wage Structure after Transition, December 2008

2512 Michel Beine, Frédéric Docquier and Maurice Schiff, International Migration, Transfers of Norms and Home Country Fertility, December 2008

2513 Dirk Schindler and Benjamin Weigert, Educational and Wage Risk: Social Insurance vs. Quality of Education, December 2008

2514 Bernd Hayo and Stefan Voigt, The Relevance of Judicial Procedure for Economic Growth, December 2008

2515 Bruno S. Frey and Susanne Neckermann, Awards in Economics - Towards a New Field of Inquiry, January 2009

2516 Gregory Gilpin and Michael Kaganovich, The Quantity and Quality of Teachers: A Dynamic Trade-off, January 2009

2517 Sascha O. Becker, Peter H. Egger and Valeria Merlo, How Low Business Tax Rates Attract Multinational Headquarters: Municipality-Level Evidence from Germany, January 2009

2518 Geir H. Bjønnes, Steinar Holden, Dagfinn Rime and Haakon O.Aa. Solheim, ,Large’ vs. ,Small' Players: A Closer Look at the Dynamics of Speculative Attacks, January 2009

2519 Jesus Crespo Cuaresma, Gernot Doppelhofer and Martin Feldkircher, The Determinants of Economic Growth in European Regions, January 2009

2520 Salvador Valdés-Prieto, The 2008 Chilean Reform to First-Pillar Pensions, January 2009

2521 Geir B. Asheim and Tapan Mitra, Sustainability and Discounted Utilitarianism in Models of Economic Growth, January 2009

2522 Etienne Farvaque and Gaël Lagadec, Electoral Control when Policies are for Sale, January 2009

2523 Nicholas Barr and Peter Diamond, Reforming Pensions, January 2009 
2524 Eric A. Hanushek and Ludger Woessmann, Do Better Schools Lead to More Growth? Cognitive Skills, Economic Outcomes, and Causation, January 2009

2525 Richard Arnott and Eren Inci, The Stability of Downtown Parking and Traffic Congestion, January 2009

2526 John Whalley, Jun Yu and Shunming Zhang, Trade Retaliation in a Monetary-Trade Model, January 2009

2527 Mathias Hoffmann and Thomas Nitschka, Securitization of Mortgage Debt, Asset Prices and International Risk Sharing, January 2009

2528 Steven Brakman and Harry Garretsen, Trade and Geography: Paul Krugman and the 2008 Nobel Prize in Economics, January 2009

2529 Bas Jacobs, Dirk Schindler and Hongyan Yang, Optimal Taxation of Risky Human Capital, January 2009

2530 Annette Alstadsæter and Erik Fjærli, Neutral Taxation of Shareholder Income? Corporate Responses to an Announced Dividend Tax, January 2009

2531 Bruno S. Frey and Susanne Neckermann, Academics Appreciate Awards - A New Aspect of Incentives in Research, January 2009

2532 Nannette Lindenberg and Frank Westermann, Common Trends and Common Cycles among Interest Rates of the G7-Countries, January 2009

2533 Erkki Koskela and Jan König, The Role of Profit Sharing in a Dual Labour Market with Flexible Outsourcing, January 2009

2534 Tomasz Michalak, Jacob Engwerda and Joseph Plasmans, Strategic Interactions between Fiscal and Monetary Authorities in a Multi-Country New-Keynesian Model of a Monetary Union, January 2009

2535 Michael Overesch and Johannes Rincke, What Drives Corporate Tax Rates Down? A Reassessment of Globalization, Tax Competition, and Dynamic Adjustment to Shocks, February 2009

2536 Xenia Matschke and Anja Schöttner, Antidumping as Strategic Trade Policy Under Asymmetric Information, February 2009

2537 John Whalley, Weimin Zhou and Xiaopeng An, Chinese Experience with Global 3G Standard-Setting, February 2009

2538 Claus Thustrup Kreiner and Nicolaj Verdelin, Optimal Provision of Public Goods: A Synthesis, February 2009

2539 Jerome L. Stein, Application of Stochastic Optimal Control to Financial Market Debt Crises, February 2009 
2540 Lars P. Feld and Jost H. Heckemeyer, FDI and Taxation: A Meta-Study, February 2009

2541 Philipp C. Bauer and Regina T. Riphahn, Age at School Entry and Intergenerational Educational Mobility, February 2009

2542 Thomas Eichner and Rüdiger Pethig, Carbon Leakage, the Green Paradox and Perfect Future Markets, February 2009

2543 M. Hashem Pesaran, Andreas Pick and Allan Timmermann, Variable Selection and Inference for Multi-period Forecasting Problems, February 2009

2544 Mathias Hoffmann and Iryna Shcherbakova, Consumption Risk Sharing over the Business Cycle: the Role of Small Firms' Access to Credit Markets, February 2009

2545 John Beirne, Guglielmo Maria Caporale, Marianne Schulze-Ghattas and Nicola Spagnolo, Volatility Spillovers and Contagion from Mature to Emerging Stock Markets, February 2009

2546 Ali Bayar and Bram Smeets, Economic and Political Determinants of Budget Deficits in the European Union: A Dynamic Random Coefficient Approach, February 2009

2547 Jan K. Brueckner and Anming Zhang, Airline Emission Charges: Effects on Airfares, Service Quality, and Aircraft Design, February 2009

2548 Dolores Messer and Stefan C. Wolter, Money Matters - Evidence from a Large-Scale Randomized Field Experiment with Vouchers for Adult Training, February 2009

2549 Johannes Rincke and Christian Traxler, Deterrence through Word of Mouth, February 2009

2550 Gabriella Legrenzi, Asymmetric and Non-Linear Adjustments in Local Fiscal Policy, February 2009

2551 Bruno S. Frey, David A. Savage and Benno Torgler, Surviving the Titanic Disaster: Economic, Natural and Social Determinants, February 2009

2552 Per Engström, Patrik Hesselius and Bertil Holmlund, Vacancy Referrals, Job Search, and the Duration of Unemployment: A Randomized Experiment, February 2009

2553 Giorgio Bellettini, Carlotta Berti Ceroni and Giovanni Prarolo, Political Persistence, Connections and Economic Growth, February 2009

2554 Steinar Holden and Fredrik Wulfsberg, Wage Rigidity, Institutions, and Inflation, February 2009

2555 Alexander Haupt and Tim Krieger, The Role of Mobility in Tax and Subsidy Competition, February 2009

2556 Harald Badinger and Peter Egger, Estimation of Higher-Order Spatial Autoregressive Panel Data Error Component Models, February 2009 
2557 Christian Keuschnigg, Corporate Taxation and the Welfare State, February 2009

2558 Marcel Gérard, Hubert Jayet and Sonia Paty, Tax Interactions among Belgian Municipalities: Does Language Matter?, February 2009

2559 António Afonso and Christophe Rault, Budgetary and External Imbalances Relationship: A Panel Data Diagnostic, February 2009

2560 Stefan Krasa and Mattias Polborn, Political Competition between Differentiated Candidates, February 2009

2561 Carsten Hefeker, Taxation, Corruption and the Exchange Rate Regime, February 2009

2562 Jiahua Che and Gerald Willmann, The Economics of a Multilateral Investment Agreement, February 2009

2563 Scott Alan Carson, Demographic, Residential, and Socioeconomic Effects on the Distribution of $19^{\text {th }}$ Century US White Statures, February 2009

2564 Philipp Harms, Oliver Lorz and Dieter Urban, Offshoring along the Production Chain, February 2009

2565 Patricia Apps, Ngo Van Long and Ray Rees, Optimal Piecewise Linear Income Taxation, February 2009

2566 John Whalley and Shunming Zhang, On the Arbitrariness of Consumption, February 2009

2567 Marie-Louise Leroux, Endogenous Differential Mortality, Non-Contractible Effort and Non Linear Taxation, March 2009

2568 Joanna Bęza-Bojanowska and Ronald MacDonald, The Behavioural Zloty/Euro Equilibrium Exchange Rate, March 2009

2569 Bart Cockx and Matteo Picchio, Are Short-Lived Jobs Stepping Stones to Long-Lasting Jobs?, March 2009

2570 David Card, Jochen Kluve and Andrea Weber, Active Labor Market Policy Evaluations: A Meta-analysis, March 2009

2571 Frederick van der Ploeg and Anthony J. Venables, Harnessing Windfall Revenues: Optimal Policies for Resource-Rich Developing Economies, March 2009

2572 Ondřej Schneider, Reforming Pensions in Europe: Economic Fundamentals and Political Factors, March 2009

2573 Jo Thori Lind, Karl Ove Moene and Fredrik Willumsen, Opium for the Masses? Conflict-Induced Narcotics Production in Afghanistan, March 2009 